\title{
İşletme Sermayesi İhtiyacının Kârlılık Üzerindeki Etkisi: Sektörel Bir Uygulama
}

\author{
Yüksel İltaş ${ }^{\mathrm{a}} \quad$ Selma Erdoğan ${ }^{\mathrm{b}}$
}

\begin{abstract}
Öz: Bu çalışmada, 2003-2013 dönemi için; nakde dönüşüm süresi, kaldıraç oranı, aktif devir hızı, Gayrisafi Yurtiçi Hasıla (GSYiH) ve Tüketici Fiyat Endeksi (TüFE) değişkenlerinin Borsa İstanbul'un seçilen dört temel (Metal, Gıda, Kimya ve Tekstil) sektörlerinin aktif karlılığı ile uzun dönem ilişkisinin tespit edilmesi amaçlanmıştır.Çalışmada, yatay kesit bağımlılığı altında ikinci nesil panel birim kök, panel eşbütünleşme, uzun ve kısa dönemli katsayı tahmini gibi ekonometrik teknikler kullanılmıştır. Analiz sonuçları değişkenlerin karlılık üzerindeki etkisinin kısa ve uzun dönemde farklılaştığını ispat etmiştir. Havuzlanmış Ortalama Grup Tahmincisi sonuçlarına göre uzun dönemde nakde dönüşüm süresinin, kaldıraç oranının ve gayri safi yurtiçi hasılanın katsayıları istatistiksel olarak anlamlıdır. Bu sonuçlara göre nakde dönüşüm süresinin uzaması kârlılık üzerinde negatif etkiye; kaldıraçtan yararlanma ve gayri safi yurtiçi hasılanın artması ise karlılık üzerinde pozitif etkiye sahiptir. Ayrıca, uzun dönem ilişkiye odaklanmak üzere uygulanan Ortak ilişkili Etkiler Ortalama Grup sonuçları da nakde dönüşüm süresi, kaldıraç oranı ve aktif devir hızı katsayılarının istatistiksel olarak anlamlı olduğunu göstermektedir.
\end{abstract}

Anahtar Sözcükler: İ̧̧letme Sermayesi, Kârlılık, Panel Eşbütünleşme

JEL Sınıflandırması: C33, G30, L25

\section{Impact of Working Capital Requirement on Profitability: A Sectoral Analysis}

Abstract: In this study, we aimed to be detected the long term co-integration relationship between, cash conversion cycle, leverage and asset turnover as the determinant of working capital requirements, Gross Domestic Product (GDP) and Consumer Price Index (CPI) as directly affecting factors of these determinants and return on assets for the 2003-2013 period of Borsa Istanbul 's selected four main sectors (metal, food, chemical, and textile). In the study, econometric techniques such as second-generation panel unit root, panel cointegration, long and short term coefficient estimation are used under cross-sectional dependence. The analysis results have proved that the effect of variables on profitability is different in short and long term. According to the Pooled Average Group Estimator results, the coefficients of the long-term cash conversion period, leverage ratio and gross domestic product are statistically significant. According to these results, the prolongation of cash conversion period has a negative effect on profitability; using leverage and increased gross domestic product have a positive impact on profitability. In addition, the Common Correlated Effects Mean Group applied to focus on the long-term relationship and it's results show that the cash conversion period, leverage ratio and asset turnover rate coefficients are statistically significant.

Keywords: Working Capital, Profitability, Panel Cointegration

JEL Classification: C33, G30, L25

\footnotetext{
${ }^{a}$ Asst. Prof., PhD., Ahi Evran University, Faculty of Economics and Administrative Sciences, Department of Business Administration, Kirsehir, Turkiye, yiltas@ahievran.edu.tr

${ }^{b}$ Res. Asst., Erciyes University, Faculty of Economics and Administrative Sciences, Department of Business Administration, Kayseri, Turkiye, selma@erciyes.edu.tr
} 


\section{Giriş}

Finans yöneticisi, işletme sermayesi yönetimi, sermaye yapısı ve sermaye bütçelemesi alanlarına odaklanarak firmanın değerini maksimize etmeye, sürdürülebilirliğini sağlamaya ve karlılı̆ını arttırmaya yönelik kararlar almaktadır, bu kararlar arasında en uzun vaktini alan karar ise işletme sermayesi yönetimi kararlarıdır.

İşletme sermayesi bir diğer adıyla çalışma sermayesi işletmelerin kısa vadeli finansman gereksinimleri ve yatırım kararlarını içermekte, işletmenin faaliyeti sonunda şekil değiştirmekte, mal ve nakit akımına neden olmaktadır (Ceylan ve Korkmaz, 2008: 192). İşletme sermayesi yönetiminde başarı sağlanması hem işletmenin sürekliliği, hem yükümlülüklerini zamanında yerine getirerek sağlayacağı prestij hem de karlılık açısından son derece önemlidir.

İşletme performansının temel göstergelerinden biri olan aktif karlılı̆ı üzerinde işletme sermayesi ihtiyacının etkisini belirlemek üzere, işletme sermayesi ihtiyacının temel göstergesi olan nakde dönüşüm süresi; işletme sermayesinin verimliliğini ortaya koyan faaliyet oranlarından aktif devir hızı ve kaynak yaratma sürecinde işletmenin riskini belirleyen kaldıraç oranı dikkate alınabilir.

Nakde dönüşüm süresi, üretim yapan işletmeler için hammadde alımı, üretim, satşs, alacaklar, tahsilat ve stoklarla tamamlanan döngüdür. Aynı döngü ticaret işletmelerinde üretim aşaması olmaksızın stoklarla başlayıp stoklarla biter. Bu süreçte işletmeler finansman maliyetlerini minimize etmek üzere etkin bir yönetim uygulamak zorundadırlar, aksi takdirde eğer finansman yabancı kaynaklardan sağlanıyorsa ek maliyetlere, özkaynaklardan sağlanıyorsa da alternatif maliyetlere katlanmaları gerekir. Dolayısıyla da nakit dönüşüm süresinin uzaması karlılığı negatif etkileyen bir unsur olarak kabul edilir. Yabancı kaynakların aktif toplamına bölünmesi suretiyle hesaplanan kaldıraç oranı işletme varlıklarının ne kadarlık bir kısmının yabancı kaynaklarla finanse edildiğini gösterir. İşletmelerin finanslama stratejileri ve dolayısıyla riske karşı tutumları hakkında bilgi veren bu oranın karlılık üzerindeki etkisi oldukça önemlidir. Aktif devir hızı ise işletme varlıklarının etkinlik derecesini gösterir. İşletme sermayesi yönetimini temsil eden bu oranın yüksek olması karlılığı olumlu yönde etkiler.

İşletmelerin başarısında, yönetim yetenekleri, işgücü, muhasebe sistemleri, uygulanan finansal teknikler gibi içsel faktörler kadar ekonomik durum, rekabet, düzenlemeler, teknoloji ve çevresel faktörler gibi dışsal faktörlerde etkilidir (Padachi, 2006: 46). Nazir ve Afza (2009), Mathuva (2010), Ukaegbu (2014), Ademola (2014) işletme sermayesi ihtiyacının karlılık üzerindeki etkisini ölçtükleri çalışmalarında dışsal faktör olarak gayrisafi yurtiçi hasılayı dikkate almışlardır. Bir ülkenin ekonomik büyüklüğünü temsil eden oranlardan GSYiH'daki değişim sadece ülke ekonomisini etkilemekle kalmayıp işletmeler ile birlikte tüm ekonomik birimleri de etkiler. Ekonomik koşullarda meydana gelen değişimler işletmeleri yakından ilgilendirmektedir. Çünkü ekonomik faaliyetler firma kazançlarını etkilemektedir. Bu bağlamda GSYiH bir ülkenin makroekonomik büyüklüğünün yani ekonomik performansının göstergesidir. GSYiH'daki değişim ülke ekonomisindeki büyümeyi ya da daralmayı açık bir şekilde göstermektedir. Bir ekonomide GSYiH arttıça bireylerin kullanılabilir gelirleri dolayısıyla da mal ve hizmetlere olan taleplerinde artı̧̧ beklenir. Ekonomik canlılıkla beraber işletmelerin saţ̧ hacimleri dolayısıyla da kârları artacaktır. TÜFE, enflasyon değerindeki yıllık değişimi ölçmek için kullanılan bir veridir ve finans yöneticilerinin planlama ufkunu etkiler. Enflasyon oranındaki artış firmaların kâr marjlarında düşüşe neden olacaktır. Enflasyon oranındaki belirsizlik ise firmaların yatıım kararlarını olumsuz etkileyecek bu durumda da kârlılık olumsuz etkilenecektir.

Bu çalışmada, işletme sermayesi gereksiniminin belirleyicilerinden nakde dönüşüm süresi, kaldıraç oranı ve aktif devir hızı ile bu belirleyicilere doğrudan etki eden GSYiH ve TÜFE değişkenlerinin Borsa İstanbul'un seçilen dört temel sektörünün (metal ana sanayi, gıda ve içecek, kimya-kauçuk ve plastik ürünler, tekstil ürünleri) aktif karlılığı ile uzun dönemli ilişkisinin tespit edilmesi amaçlanmıştır. Bu amaç doğrultusunda çalışma da, 2003-2013 dönemi verileri kullanılarak, yatay kesit bağımlılı̆ını göz önünde bulunduran panel birim kök ve panel eşbütünleşme analizi yöntemleri kullanılmıştır. 
Çalışmanın önemi, amacı ve yöntemini açıklayan giriş kısmından sonra, ikinci kısımda literatür incelemesi yapılmış, üçüncü kısımda veri seti oluşturulmuş, dördüncü kısım da ekonometrik metodolojiye yer verildikten sonra, beşinci kısım da sonuçlarla çalışma sonlandırımıştır.

\section{Literatür İncelemesi}

İşletme sermayesinin kârlılık üzerindeki etkisini ölçen yabancı ve yerli çalışmaların özet bilgileri sırasıyla Tablo 1 ve Tablo 2'de gösterilmiştir.

Tablo 1'de görüldügü üzere gelişmiş ve gelişmekte olan ülkelere yönelik yapılan çalışmalarda ağırıklı olarak regresyon analizi kullanılmıştır. İncelen bu çalışmalar sonucunda karlılık ile nakde dönüşüm süresi, alacakların tahsil süresi, stok tutma süresi ve borçların ödenme süresi arasında negatif yönlü ilişkilerin tespit edildiği görülmüştür.

Tablo 1. Gelişmiş ve Gelişmekte Olan Ülke Ekonomilerine Yönelik Literatür Özeti

\begin{tabular}{|c|c|c|c|c|c|}
\hline 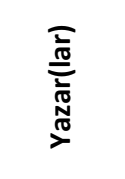 & Veri Seti & Metodoloji & 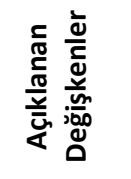 & Açıklayıcı Değişkenler & Bulgular \\
\hline 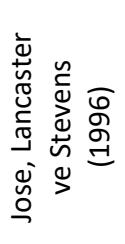 & $\begin{array}{l}\text { Compustat } \\
\text { Verileri, } \\
7 \text { Farklı } \\
\text { Sektörden } \\
2.718 \text { Firma, } \\
\text { 1974-1993 }\end{array}$ & $\begin{array}{l}\text { Çoklu } \\
\text { Regresyon, } \\
\text { Non- } \\
\text { Parametrik } \\
\text { Testler }\end{array}$ & 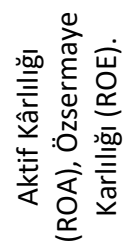 & $\begin{array}{l}\text { Nakit Dönüşüm Süresi } \\
\text { (CCC). }\end{array}$ & $\begin{array}{l}\text { Bütün sektörler de CCC ile ROA arasında } \\
\text { istatistiki olarak anlamlı ve negatif bir ilişkinin } \\
\text { varlığı; ROA yerine ROE kullanılı̆ğında da } \\
\text { korelasyonun farklı olmadığı tespit edilmiştir. }\end{array}$ \\
\hline 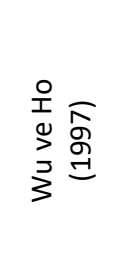 & $\begin{array}{l}105 \text { Amerikan } \\
\text { Firması, } \\
\text { 1973-1992 }\end{array}$ & $\begin{array}{l}\text { Zaman } \\
\text { Serisi ve } \\
\text { Yatay Kesit } \\
\text { Regresyonu }\end{array}$ & 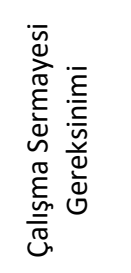 & $\begin{array}{l}\text { Cari Oran, Likidite } \\
\text { Oranı, } \\
\text { Özkaynak/Toplam } \\
\text { Borç, } \\
\text { Stok ve Aktif Devir } \\
\text { Hızı, Net Faaliyet } \\
\text { Karı/Varlıklar. }\end{array}$ & $\begin{array}{l}\text { Finansal oranların hem dışsal şoklardan hem } \\
\text { de yöneticilerin bu oranları, hedefledikleri } \\
\text { oranlara yaklaştırma girişimlerinden önemli } \\
\text { ölçüde etkilendiği bulgusuna ulaşılmıştır. }\end{array}$ \\
\hline
\end{tabular}

\begin{tabular}{|c|c|c|c|c|c|}
\hline 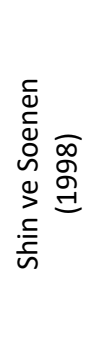 & $\begin{array}{l}\text { Amerikan } \\
\text { Firmaları, } \\
58.985 \\
\text { Gözlem, } \\
\text { 1975-1994 }\end{array}$ & Regresyon & 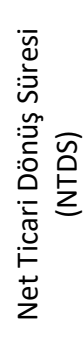 & $\begin{array}{l}\text { (Faaliyet Kârı + } \\
\text { Amortismanlar)/Topla } \\
\text { m Aktif Oranı, } \\
\text { (Faaliyet Kârı + } \\
\text { Amortismanlar)/Net } \\
\text { Satışlar Oranı, Cari } \\
\text { Oran, Borç Oranı, } \\
\text { Satışlardaki Büyüme. }\end{array}$ & $\begin{array}{l}\text { NTDS ile firma kârlılığı arasında güçlü negatif } \\
\text { bir iliş̧i olduğu; NTDS'si (\%1 anlam } \\
\text { düzeyinde) kısa olan firmaların daha kârlı } \\
\text { olduğu ve toplam risk birimi başına daha } \\
\text { yüksek risk ayarlı hisse getirisine sahip } \\
\text { oldukları; firmaların hisse senedi getirilerin } \\
\text { de NTDS'nin uzunluğu ile istatistiksel olarak } \\
\text { anlamlı düzeyde negatif ilişkili oldukları tespit } \\
\text { edilmiştir. }\end{array}$ \\
\hline 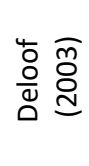 & $\begin{array}{l}\text { Belçika } \\
\text { Firmaları, } \\
\text { 1009 Firma, } \\
\text { 1992-1996 }\end{array}$ & Regresyon & ర్ & $\begin{array}{l}\text { Alacakların Tahsil } \\
\text { Süresi, Stok Tutma } \\
\text { Süresi, Nakit } \\
\text { Dönüşüm Süresi }\end{array}$ & $\begin{array}{l}\text { Firma kârıılığı ile alacak tahsil süresi, stok } \\
\text { tutma süresi ve borçları erteleme arasında } \\
\text { istatistiksel olarak anlamlı negatif bir ilişkinin } \\
\text { varlığı tespit edilmiştir. }\end{array}$ \\
\hline 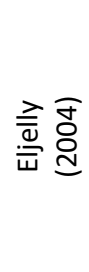 & $\begin{array}{l}\text { Suudi } \\
\text { Arabistan } \\
\text { Firmaları, } \\
\text { 1996-2000 }\end{array}$ & Regresyon & $\underset{\Upsilon ્}{\mathbb{\Upsilon}}$ & $\begin{array}{l}\text { Net Satışlar, Toplam } \\
\text { Varlıklar, Nakit } \\
\text { Dönüşüm Süresi, Cari } \\
\text { Oran, (Faaliyet Kârı + } \\
\text { Amortismanlar)/Net } \\
\text { Satışlar }\end{array}$ & $\begin{array}{l}\text { Firma kârııı̆̆ı ve likiditesi arasında negatif bir } \\
\text { ilişki, endüstri düzeyinde firma büyüklüğünün } \\
\text { kârlılık üzerinde etkisinin olduğu ve nakit } \\
\text { dönüşüm süresinin kârlılık üzerindeki } \\
\text { etkisinin cari oranın kârlılık üzerindeki } \\
\text { etkisine kıyasla daha fazla olduğu tespit } \\
\text { edilmiştir. }\end{array}$ \\
\hline
\end{tabular}




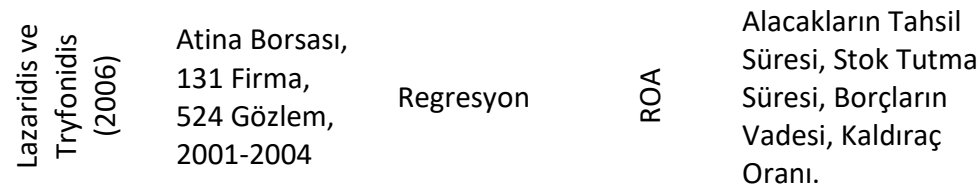

\begin{tabular}{|c|c|c|c|c|c|}
\hline 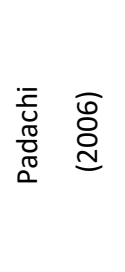 & $\begin{array}{l}58 \text { Küçük } \\
\text { Ölçekli } \\
\text { Moritanya } \\
\text { Firması, } \\
\text { 1998-2003 }\end{array}$ & $\begin{array}{l}\text { Panel Veri } \\
\text { Analizi ve } \\
\text { Regresyon }\end{array}$ & 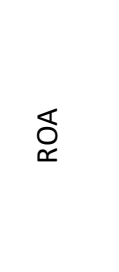 & $\begin{array}{l}\text { Nakit Dönüşüm } \\
\text { Süresi, Firma Boyutu, } \\
\text { Kaldıraç Oranı, Brüt } \\
\text { İşletme Sermayesi } \\
\text { Devir Hızı,Dönen } \\
\text { Varlık/Toplam } \\
\text { Aktifler. }\end{array}$ & $\begin{array}{l}\text { Alacaklara ve stoklara yüksek oranda } \\
\text { yatırımın işletmelerde kârlıı̆ı azalttığı ve } \\
\text { nakit dönüşüm süresinin uzaması ile işletme } \\
\text { kârlıığının azaldığı tespit edilmiştir. }\end{array}$ \\
\hline 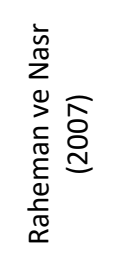 & $\begin{array}{l}\text { Karachi } \\
\text { Menkul } \\
\text { Kıymetler } \\
\text { Borsası, } \\
94 \text { Pakistan } \\
\text { Firması, } \\
\text { 1999-2004 }\end{array}$ & $\begin{array}{l}\text { Pearson } \\
\text { Korelasyonu } \\
\text {, Regresyon }\end{array}$ & 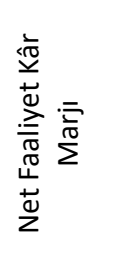 & $\begin{array}{l}\text { Nakde Dönüşüm } \\
\text { Süresi, Firma Boyutu, } \\
\text { Kaldıraç Oranı, } \\
\text { Finansal } \\
\text { Varlıklar/Toplam } \\
\text { Varlıklar Oranı }\end{array}$ & $\begin{array}{l}\text { Alacak tahsil süresi, stok tutma süresi, } \\
\text { borçların ödenme süresi, nakit dönüşüm } \\
\text { süresi, cari oran ile firma kârlılığı arasında } \\
\text { güçlü negatif iliş̧i saptanmıştır. Kârıııı ile } \\
\text { likidite arasında istatistiksel olarak anlamlı } \\
\text { negatif ilişki; firma boyutuyla ise pozitif ilişki } \\
\text { tespit edilmiştir. }\end{array}$ \\
\hline 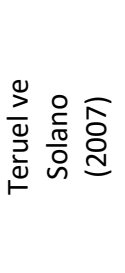 & $\begin{array}{l}\text { İspanya } \\
\text { Borsası, } \\
8.872 \text { Firma, } \\
1996-2002\end{array}$ & $\begin{array}{l}\text { Panel Veri } \\
\text { Analizi ve } \\
\text { Regresyon }\end{array}$ & 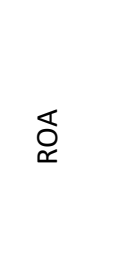 & $\begin{array}{l}\text { Alacakların Tahsil } \\
\text { Süresi, Stok Devir } \\
\text { Süresi, } \\
\text { Borçların Ortalama } \\
\text { Vadesi, Büyüklük, } \\
\text { Satışların Büyümesi, } \\
\text { Kaldıraç Oranı. }\end{array}$ & $\begin{array}{l}\text { İşletme sermayesi yönetimi ile aktif kârlılığı } \\
\text { ile ölçülen kârlılık arasında negatif bir ilişki } \\
\text { belirlenmiştir. Firma kârlılığı ile alacak tahsil } \\
\text { süresi ve stok tutma süresi arasında negatif } \\
\text { ilişki vardır. }\end{array}$ \\
\hline 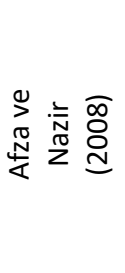 & $\begin{array}{l}\text { Karachi } \\
\text { Menkul } \\
\text { Kıymetler } \\
\text { Borsası, } 17 \\
\text { Farklı Sektör, } \\
263 \text { Firma, } \\
1998-2003\end{array}$ & $\begin{array}{l}\text { Regresyon } \\
\text { (En Küçük } \\
\text { Kareler ) }\end{array}$ & $\begin{array}{l}\text { 岁 } \\
\propto \\
\overleftarrow{O} \\
\&\end{array}$ & $\begin{array}{l}\text { Dönen Varlık/Aktif } \\
\text { Toplamı, KVYK/Aktif } \\
\text { Toplamı. }\end{array}$ & $\begin{array}{l}\text { Finansman politikaları ve işletme sermayesi } \\
\text { yatırımlarının atılganlık derecesi ile firma } \\
\text { kârııı̆ı arasında negatif, finansman } \\
\text { politikaları ve varlık yönetimi politikaları } \\
\text { arasında negatif bir ilişki tespit edilmiştir. }\end{array}$ \\
\hline 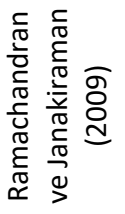 & $\begin{array}{l}\text { Hindistan } \\
\text { Kâğıt Sektörü, } \\
37 \text { Firma, } \\
\text { 1997-2006 }\end{array}$ & Regresyon & 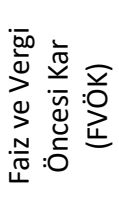 & $\begin{array}{l}\text { İşletme Sermayesi } \\
\text { Etkinliği, Nakit } \\
\text { Dönüşüm Süresi. }\end{array}$ & $\begin{array}{l}\text { Faiz ve vergi öncesi kâr ile nakde dönüşüm } \\
\text { süresi ve borçların ödenme süresi arasında } \\
\text { negatif yönlü bir ilişki bulunmuştur. }\end{array}$ \\
\hline 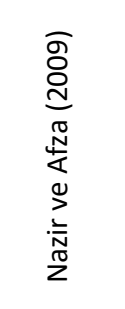 & $\begin{array}{l}\text { Karachi } \\
\text { Menkul } \\
\text { Kıymetler } \\
\text { Borsası, } \\
132 \text { imalat } \\
\text { firması }\end{array}$ & $\begin{array}{l}\text { Panel Veri } \\
\text { Analizi ve } \\
\text { Regresyon }\end{array}$ & 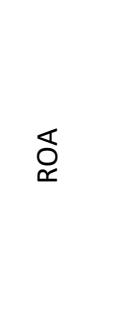 & $\begin{array}{l}\text { Dönen Varlık/Aktif } \\
\text { Toplamı, KVYK/Aktif } \\
\text { Toplamı, Firma } \\
\text { Boyutu, Kaldıraç } \\
\text { Oranı, Tobin Q, Reel } \\
\text { GSYH Büyüme Oranı. }\end{array}$ & $\begin{array}{l}\text { İşletme sermayesi ihtiyacı ile faaliyet } \\
\text { döngüsü, Tobin Q, ROA, faaliyetlerden nakit } \\
\text { akışları, reel GSYH büyüme oranı, satışların } \\
\text { büyümesi ve firma boyutu arasında pozitif } \\
\text { yönlü ilişki tespit edilmiştir. Ayrıca firma } \\
\text { kaldıracı ile işletme sermayesi ihtiyacı } \\
\text { arasında güçlü ve negatif bir ilişkinin varlığı } \\
\text { tespit edilmiştir. }\end{array}$ \\
\hline
\end{tabular}

Firma kârlılığı ile alacak tahsil süresi, stok tutma süresi ve borçların ödenme süresi arasındaki ilişki negatiftir. Nakde dönüşüm süresinin uzaması karlılığı olumsuz yönde etkilemiştir. 


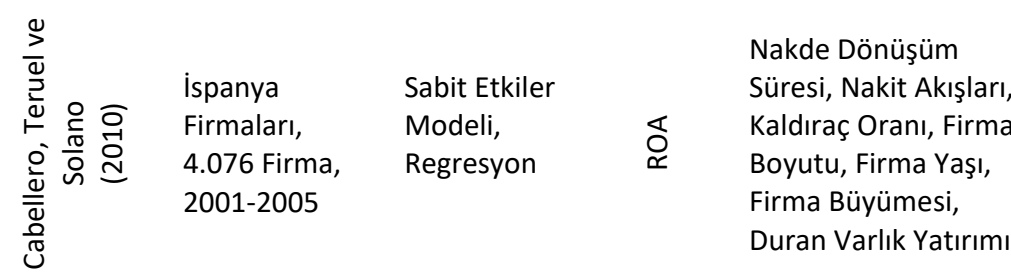

Uzun nakit dönüşüm sürecine sahip firmalar, daha fazla nakit akışı olan büyük firmalardır. Ayrıca nakit dönüşüm süreci ile borç oranı, firma büyümesi, maddi duran varlık yatırımları arasında pozitif bir ilişki tespit edilirken; varlıkların kazanma gücü ile negatif bir ilişki tespit edilmiştir. GSYH'nın nakit dönüşüm süresi üzerinde etkisi olduğuna dair kanıt bulunamamıştır.

\begin{tabular}{|c|c|c|c|c|c|}
\hline 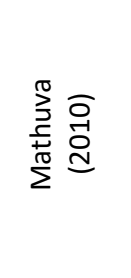 & $\begin{array}{l}\text { Nairobi Menkul } \\
\text { Kıymetler } \\
\text { Borsası'na } \\
\text { Kayıtlı } 30 \\
\text { Firma, } \\
468 \text { Gözlem, } \\
\text { 1993-2008 }\end{array}$ & $\begin{array}{l}\text { Sabit Etkiler } \\
\text { Modeli, } \\
\text { Regresyon }\end{array}$ & 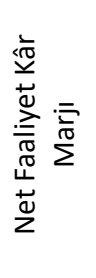 & $\begin{array}{l}\text { Nakde Dönüşüm } \\
\text { Süresi, Firma Boyutu, } \\
\text { Kaldıraç Oranı, Maddi } \\
\text { Duran Varlıklar/ } \\
\text { Toplam Varlıklar } \\
\text { Oranı ve GSYH Oranı }\end{array}$ & $\begin{array}{l}\text { Alacak tahsil süresi ile kârlıık arasında önemli } \\
\text { düzeyde negatif ilişki, stok bulundurma süresi } \\
\text { ve borç ödeme süresi ile kârlılık arasında ise } \\
\text { güçlü düzeyde pozitif iliş̧ki ve \% } 10 \text { anlam } \\
\text { düzeyinde geçerli olan nakit dönüşüm süresi } \\
\text { ile kârlılık arasında negatif ilişki tespit } \\
\text { edilmiştir. }\end{array}$ \\
\hline 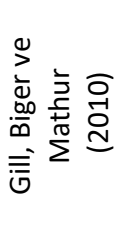 & $\begin{array}{l}\text { New York } \\
\text { Borsası'na } \\
\text { Kayıtlı } 88 \\
\text { İmalat Firması, } \\
264 \text { Gözlem, } \\
\text { 2005-2007 }\end{array}$ & $\begin{array}{l}\text { Panel Veri } \\
\text { ve } \\
\text { Regresyon }\end{array}$ & 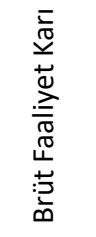 & $\begin{array}{l}\text { Nakde Dönüşüm } \\
\text { Süresi, Firma Boyutu, } \\
\text { Kaldıraç Oranı, Duran } \\
\text { Varlık / Toplam } \\
\text { Aktifler. }\end{array}$ & $\begin{array}{l}\text { Firma kârlılığı ile alacak tahsil süresi arasında } \\
\text { negatif ilişki tespit edilmiş, firma kârlıığı ile } \\
\text { stok tutma süresi arasında ise istatistiksel } \\
\text { olarak anlamlı bir ilişki saptanmamıştır. Nakit } \\
\text { dönüşüm süresi ile brüt faaliyet kârı arasında } \\
\text { pozitif ilişki tespit edilmiştir. }\end{array}$ \\
\hline 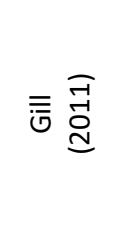 & $\begin{array}{l}\text { Toronto } \\
\text { Borsası'nda } \\
\text { İşlem Gören } \\
166 \text { Kanada } \\
\text { Firması, } \\
2008-2010\end{array}$ & $\begin{array}{l}\text { Panel Veri } \\
\text { Analizi ve } \\
\text { Regresyon }\end{array}$ & $\underset{\Upsilon}{\overleftarrow{O}}$ & $\begin{array}{l}\text { Faaliyet Döngüsü, } \\
\text { Firma Büyümesi, } \\
\text { Tobin Q, Kaldıraç } \\
\text { Oranı, Firma Boyutu, } \\
\text { Uluslararasılaşma } \\
\text { Derecesi. }\end{array}$ & $\begin{array}{l}\text { İmalat sektöründe işletme sermayesi } \\
\text { gereksinimini faaliyet döngüsü, aktif kârlılığı, } \\
\text { firmanın uluslararasılaşma düzeyi ve işletme } \\
\text { ölçeği etkilemektedir. }\end{array}$ \\
\hline 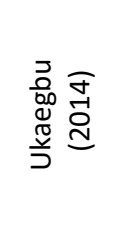 & $\begin{array}{l}\text { Mısır, Kenya, } \\
\text { Nijerya ve } \\
\text { Güney Afrika, } \\
\text { İmalat Sektörü } \\
\text { Firmaları, } \\
\text { 2005-2009 }\end{array}$ & $\begin{array}{l}\text { Çoklu } \\
\text { Regresyon, } \\
\text { Chow Testi, }\end{array}$ & 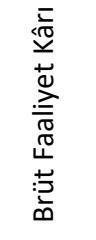 & $\begin{array}{l}\text { Nakde Dönüşüm } \\
\text { Süresi, GSYH, Firma } \\
\text { Boyutu }\end{array}$ & $\begin{array}{l}\text { Kârlılık ile nakde dönüşüm süresi ve alacak } \\
\text { tahsil süresi arasında negatif; kârlılık ile firma } \\
\text { boyutu arasında da pozitif bir ilişki tespit } \\
\text { edilmiştir. }\end{array}$ \\
\hline $\begin{array}{l}\frac{\pi}{d} \\
\stackrel{D}{D} \\
\frac{\pi}{0} \\
\frac{0}{0} \\
\frac{0}{0} \\
\frac{0}{2}\end{array}$ & $\begin{array}{l}\text { Nijerya Gıda ve } \\
\text { İçecek Sektörü, } \\
12 \text { Firma, } \\
2002-2011\end{array}$ & $\begin{array}{l}\text { Korelasyon } \\
\text { Analizi ve } \\
\text { Çoklu } \\
\text { Regresyon }\end{array}$ & 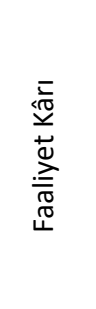 & $\begin{array}{l}\text { Alacak Devir Hızı, Stok } \\
\text { Devir Hızı, Nakde } \\
\text { Dönüşüm Süresi, Kısa } \\
\text { Vadeli Borç Devir Hızı, } \\
\text { Cari Oran, Kaldıraç } \\
\text { Oranı, Satışların } \\
\text { Büyümesi ve Gayrisafi } \\
\text { Yurtiçi Hâsıla. }\end{array}$ & $\begin{array}{l}\text { Alacak devir hızı, satışların büyümesi, kaldıraç } \\
\text { oranı ve GSYH ile kârlılık arasında pozitif } \\
\text { yönlü; stok devir hızı, kısa vadeli borç devir } \\
\text { hızı ve cari oran ile kârlılık arasında negatif } \\
\text { yönlü ilişki tespit edilmiştir. Kârlııı ile nakde } \\
\text { dönüşüm süresi arasında pozitif yönlü ancak } \\
\text { istatistiksel olarak anlamsız ilişki } \\
\text { bulunmuştur. }\end{array}$ \\
\hline
\end{tabular}

Türkiye'de faaliyet gösteren işletmeler üzerine yapılan çalışmalar genellikle Borsa İstanbul'a (BiST) kayıtlı şirketler üzerinden yapılan değerlendirmelerdir. Tablo 2'de görüldüğü üzere gelişmiş ve gelişmekte olan ülkelerde yapılan çalışmalarda olduğu gibi regresyon ve panel veri analizi uygulamaları yöntem olarak ağırlık taşımaktadır. Bulgulara bakıldığında genel olarak uluslararası literatürle uyumlu sonuçlar gözlemlenmiştir. 
Tablo 2. Türkiye Ekonomisine Yönelik Literatür Özeti

\begin{tabular}{|c|c|c|c|c|c|}
\hline 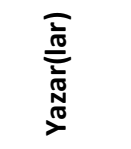 & Veri Seti & Metodoloji & 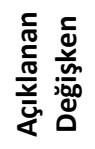 & $\begin{array}{c}\text { Açıklayıcı } \\
\text { Değişkenler }\end{array}$ & Bulgular \\
\hline 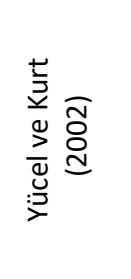 & $\begin{array}{l}\text { Borsa İstanbul } \\
\text { (BisT)'da İşlem } \\
\text { Gören } 167 \text { Firma, } \\
\text { 1995-2000 }\end{array}$ & Regresyon & 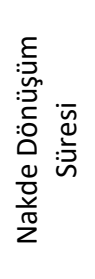 & $\begin{array}{l}\text { Net Kar Marjı, Aktif } \\
\text { Karlıı̆ı̆ı, } \\
\text { Özsermaye } \\
\text { Karııı̆̆ı, Cari } \\
\text { Oran,Likidite } \\
\text { Oranı, Kaldıraç } \\
\text { Oranı. }\end{array}$ & $\begin{array}{l}\text { Nakit dönüş süresinin likidite oranları ile } \\
\text { pozitif, aktif kârlıı̆ı̆ı ve özsermaye kârlılığı ile } \\
\text { negatif ilişkisi tespit edilmiştir. Nakit dönüş } \\
\text { süresinin dönemsel olarak farklı olmadığı, } \\
\text { buna karşılık sektörler ve işletme ölçeğine } \\
\text { göre istatistiksel olarak anlamlı farklılıklar } \\
\text { olduğu ortaya konmuştur. }\end{array}$ \\
\hline 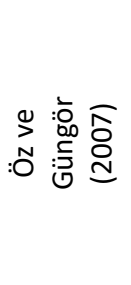 & $\begin{array}{l}\text { BiST İmalat Sektörü, } \\
68 \text { Firma, } \\
\text { 1992-2005 }\end{array}$ & $\begin{array}{l}\text { Panel Veri } \\
\text { Analizi ve } \\
\text { Regresyon }\end{array}$ & 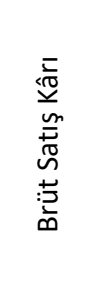 & $\begin{array}{l}\text { Alacakların Tahsil } \\
\text { Süresi, Stok Tutma } \\
\text { Süresi, Borçların } \\
\text { Vadesi, Net Ticaret } \\
\text { Süresi, Firma } \\
\text { Büyüklüğü. }\end{array}$ & $\begin{array}{l}\text { Firma kârlıı̆ı ile çalışma sermayesi } \\
\text { yönetimini temsil eden alacak devir hızı, borç } \\
\text { devir hızı, stok devir hızı ve net ticaret süresi } \\
\text { arasında negatif, satışlardaki büyüme ve mali } \\
\text { duran varlıkların toplam aktiflere oranı } \\
\text { arasında pozitif ve istatistiksel olarak anlamlı } \\
\text { bir iliş̧i tespit edilmiştir. }\end{array}$ \\
\hline 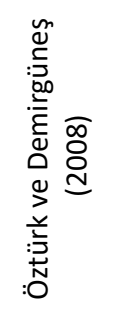 & $\begin{array}{l}\text { BiST, } \\
\text { Metal Eşya, Makine } \\
\text { ve Gereç Yapım } \\
\text { Sektörü, } \\
\text { 2002-2006 }\end{array}$ & Regresyon & 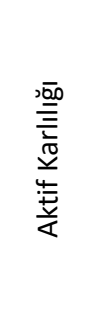 & $\begin{array}{l}\text { Alacakların Tahsil } \\
\text { Süresi, } \\
\text { Stok Tutma Süresi, } \\
\text { Nakde Dönüşüm } \\
\text { Süresi, } \\
\text { Kaldıraç Oranı, } \\
\text { Satışlardaki } \\
\text { Büyüme. }\end{array}$ & $\begin{array}{l}\text { Kaldıraç oranının, aktif kârlılı̆ı̆ın ve } \\
\text { büyümenin işletme sermayesi gereksinimini } \\
\text { istatistiksel olarak anlamlı bir biçimde } \\
\text { etkilediği sonucuna ulaşılmıştır. }\end{array}$ \\
\hline 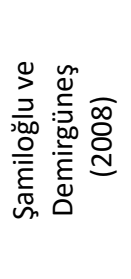 & $\begin{array}{l}\text { BiST İmalat Sektörü, } \\
5.843 \text { Gözlem, } \\
1998-2007\end{array}$ & $\begin{array}{l}\text { Çoklu } \\
\text { Regresyon }\end{array}$ & ঠิ & $\begin{array}{l}\text { Nakde Dönüşüm } \\
\text { Süresi, Firma } \\
\text { Boyutu, Kaldıraç } \\
\text { Oranı, Maddi } \\
\text { Duran } \\
\text { Varlıklar/Aktif } \\
\text { Toplamı. }\end{array}$ & $\begin{array}{l}\text { Nakit dönüşüm döngüsü, firma boyutu ve } \\
\text { maddi duran varlıklar/toplam varlıklar oranı } \\
\text { ile firma kârlılığı arasında istatistiki olarak } \\
\text { anlamlı bir ilişkinin olmadığı sonucuna } \\
\text { ulaşılmıştır. }\end{array}$ \\
\hline 龒宫 & $\begin{array}{l}\text { BisT, Perakende ve } \\
\text { İmalat Sektöründe } \\
\text { İşlem Gören } 166 \\
\text { Firma, } \\
2007\end{array}$ & $\begin{array}{l}\text { ANOVA ve } \\
\text { Pearson } \\
\text { Korelasyon }\end{array}$ & & $\begin{array}{l}\text { Nakde Dönüşüm } \\
\text { Süresi, Aktif } \\
\text { Toplamı, Net } \\
\text { Satışlar. }\end{array}$ & $\begin{array}{l}\text { Nakit döngüsü uzunluğunun net satışlar ve } \\
\text { toplam varlıklar bakımından firma boyutu ile } \\
\text { anlamlııı seviyesinde negatif bir ilişkiye } \\
\text { sahip olduğu ortaya konmuştur. Nakit } \\
\text { döngüsü uzunluğu ile firma kârlılığı arasında } \\
\text { istatistiksel olarak anlamlı ve negatif bir } \\
\text { korelasyon tespit edilmiş̧tir. }\end{array}$ \\
\hline 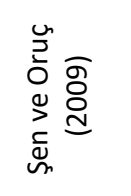 & $\begin{array}{l}\text { BiST İmalat Sektörü, } \\
49 \text { Firma, } \\
\text { 1993-2007 }\end{array}$ & $\begin{array}{l}\text { Sabit Etkiler } \\
\text { ve Tesadüfü } \\
\text { Etkiler } \\
\text { Modeli, } \\
\text { Regresyon }\end{array}$ & ષ્ઞ & $\begin{array}{l}\text { Nakde Dönüşüm } \\
\text { Süresi, Cari Oran, } \\
\text { Net İşletme } \\
\text { Sermayesi. }\end{array}$ & $\begin{array}{l}\text { Cari oran, net işletme sermayesi düzeyi, nakit } \\
\text { döngüsü, alacak tahsil süresi, stok } \\
\text { bulundurma süresi ile aktif kârlılığı arasında } \\
\text { negatif bir ilişki ortaya konmuştur. }\end{array}$ \\
\hline
\end{tabular}


BisT İmalat Sektörü,

154 Firma,

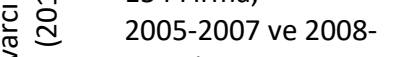

焉 $2009 /(1-9$ ay)

:
En Küçük

Kareler

Yöntemi
ROA, ROE, Kaldıraç Oranı, FAVÖK, Satışlardaki Büyüme, Alacak Tahsil Süresi, Stok Tutma Süresi, Brüt Kâr Marjı, Net Kâr Marjı, Duran Varlık Oranı, Tobin Q.
Kaldıraç oranı ve duran varlık oranındaki artış hem kriz olmayan dönemde hem de kriz dönemlerinde çalışma sermayesi gereksinimini azaltmaktadır. Stok devir hızı ve Tobin $Q$ değeri kriz öncesi dönemlerde çalışma sermayesi gereksinimi üzerinde herhangi bir etki göstermezken kriz dönemlerinde çalışma sermayesi gereksinimini azaltmaktadır.

\begin{tabular}{|c|c|c|c|c|}
\hline 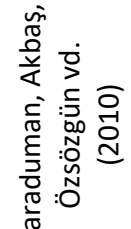 & $\begin{array}{l}\text { BiST, } \\
140 \text { Firma, } \\
\text { 2005-2008 }\end{array}$ & $\begin{array}{l}\text { Panel Veri } \\
\text { Analizi ve } \\
\text { Regresyon }\end{array}$ & ర্ৰ & $\begin{array}{l}\text { Nakde Dönüşüm } \\
\text { Süresi, Kaldıraç } \\
\text { Oranı, Firma } \\
\text { Büyüklüğü, GSYH. }\end{array}$ \\
\hline
\end{tabular}

Firma varlıklarının getirisinin artırılması; alacak tahsil, stok tutma ve borç ödeme süresinin kısaltılması ile mümkündür. Aktif kârlılı̆ı ile kaldıraç oranı ve nakit dönüşüm süresi arasında negatif; firma boyutu ile arasında pozitif ilişkinin varlığı tespit edilmiştir.

Aktif kârılığı ile aktif dönüş süresi, alacak tahsil süresi ve stok devir süresi arasında negatif; borç ödeme süresi arasında pozitif ilişki tespit edilmiştir.

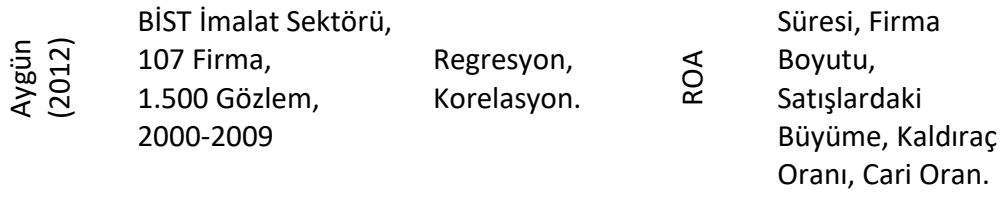

竞
PD/DD, Likidite U Oranları, Alacak BiST İmalat Sektörü, Panel Veri 122 Firma, 2000-2009 Analizi, Regresyon
Devir Hızı, Stok

Devir Hızı, Aktif

Devir Hızı, Kısa Vadeli Borç Oranı.
Nakit dönüşüm süresi ile firma performansı ve firma büyüklüğü arasında negatif ve istatistiksel olarak oldukça istatistiksel olarak anlamlı sonuçlar elde edilmiştir.

Cari oran ve kaldıraç oranının aktif kârlıığıyla negatif ilişkili olduğu, asit test oranı, stok devir hızı ve aktif devir hızının ise kârııığa pozitif ve istatiksel olarak anlamlı etkisinin olduğu;iş̧letme sermayesi unsurları ile özsermaye kârlılı̆̆ı ve piyasa değeri arasında istatistiksel olarak anlamlı bir ilişki olmadığı gözlemlenmiştir.

\begin{tabular}{|c|c|c|c|c|c|}
\hline 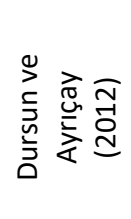 & $\begin{array}{l}\text { BIST } \\
120 \text { Üretim ve } \\
\text { Ticaret Firması, } \\
\text { 1.200 Gözlem, } \\
\text { 1995-2005 }\end{array}$ & $\begin{array}{l}\text { En Küçük } \\
\text { Kareler } \\
\text { ve } \\
\text { Sabit Etkiler } \\
\text { Modeli }\end{array}$ & 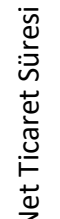 & $\begin{array}{l}\text { Brüt Satış Kârı, } \\
\text { Firma Büyüklüğü, } \\
\text { Kaldıraç Oranı, } \\
\text { Finansal Duran } \\
\text { Varlık Oranı. }\end{array}$ & $\begin{array}{l}\text { Brüt karlılık ile stok devir süresi, borç ödeme } \\
\text { süresi ve net ticaret süresi arasında } \\
\text { istatistiksel olarak anlamlı negatif ilişki tespit } \\
\text { edilmiştir. }\end{array}$ \\
\hline
\end{tabular}

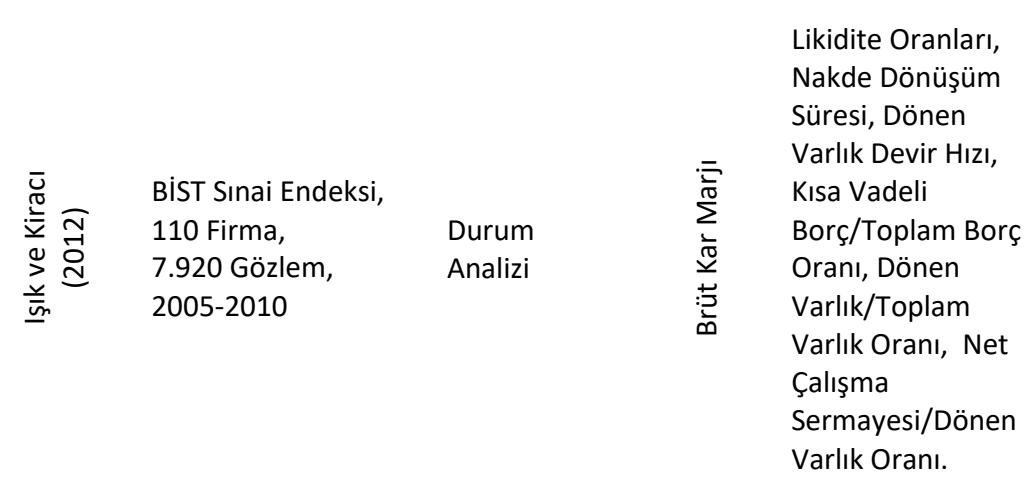

Kriz öncesi ve sonrası üç yıllık dönemde, likidite oranları değişmezken, faaliyet oranlarının azaldığı ve bunun sonucu olarak brüt kâr oranlarının azaldığı tespit edilmiştir. 2007-2008 yılları için likidite ile faaliyet oranlarının 2008 yılında 2007 yılına göre düştüğü, brüt kâr oranının azaldığı sonucu bulunmuştur. 


\begin{tabular}{|c|c|c|c|c|c|}
\hline 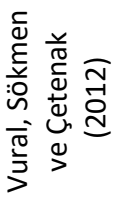 & $\begin{array}{l}\text { BiST İmalat Sektörü, } \\
75 \text { Firma, } \\
600 \text { Gözlem, } \\
2002-2009\end{array}$ & $\begin{array}{l}\text { Dinamik } \\
\text { Panel, } \\
\text { Regresyon }\end{array}$ & 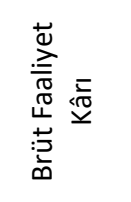 & $\begin{array}{l}\text { Nakde Dönüşüm } \\
\text { Süresi, Firma } \\
\text { Boyutu, Kaldıraç } \\
\text { Oranı, Tobin Q. }\end{array}$ & $\begin{array}{l}\text { Alacak tahsil süresi ve nakit dönüşüm süresi } \\
\text { firma kârlılığ ile negatif ilişkilidir. Firma } \\
\text { değeri ile kaldıraç oranı arasında negatif; } \\
\text { nakit dönüşüm döngüsü ile firma değeri } \\
\text { arasında da pozitif bir ilişki tespit edilmiştir. }\end{array}$ \\
\hline 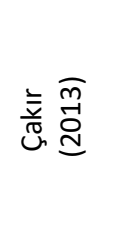 & $\begin{array}{l}\text { BisT, İmalat Sektörü, } \\
52 \text { Firma, } \\
2000-2010\end{array}$ & Regresyon & 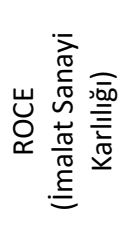 & $\begin{array}{l}\text { FVÖK/Devamlı } \\
\text { Sermaye, Aktif } \\
\text { Devir Hızı, Nakde } \\
\text { Dönüşüm Süresi, } \\
\text { Kısa Vadeli Borç } \\
\text { Ödeme Süresi. }\end{array}$ & $\begin{array}{l}\text { İmalat sanayi beklenenin aksine işletmelerin } \\
\text { nakit dönüşüm süresini artırarak kârlııklarını } \\
\text { artırabilecekleri sonucuna ulaşılmıştır. Kimya } \\
\text { ve taş alt sektörlerinde ise kârlıık ile nakit } \\
\text { dönüşüm süresi arasında ters yönlü bir ilişki } \\
\text { bulunmuştur. }\end{array}$ \\
\hline 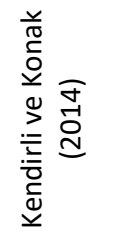 & $\begin{array}{l}\text { BisT Gıda ve İçecek } \\
\text { Sektörü, } \\
18 \text { Firma, } \\
2008-2012\end{array}$ & $\begin{array}{l}\text { Çoklu } \\
\text { Regresyon }\end{array}$ & 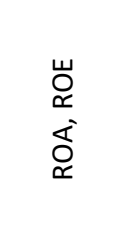 & $\begin{array}{l}\text { Tobin Q, Alacak } \\
\text { Devir Hızı, Stok } \\
\text { Devir Hızı ve Kısa } \\
\text { Vadeli Borç Devir } \\
\text { Hızı ve Nakde } \\
\text { Dönüşüm Süresi. }\end{array}$ & $\begin{array}{l}\text { Nakde dönüşüm süresi ve alacak devir hızı ile } \\
\text { ROA ve ROE arasında } \% 10 \text { anlam düzeyinde } \\
\text { negatif yönlü ilişsi tespit edilirken, Tobins'q } \\
\text { açısından negatif ilişki istatistiksel açıdan } \\
\text { anlamlı olmadığı sonucu bulunmuştur. }\end{array}$ \\
\hline 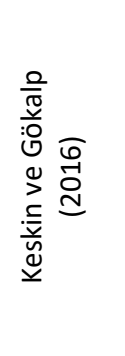 & $\begin{array}{l}\text { BiST Gıda ve İçecek } \\
\text { Sektörü, } \\
17 \text { Firma, } \\
2009-2013\end{array}$ & $\begin{array}{l}\text { Panel Veri } \\
\text { Analizi }\end{array}$ & ర્વ & $\begin{array}{l}\text { Nakde Dönüşüm } \\
\text { Süresi, Alacak } \\
\text { Devir Hızı, Stok } \\
\text { Devir Hızı, Borç } \\
\text { Ödeme Süresi, Cari } \\
\text { Oran, Firma } \\
\text { Büyüklüğü ve Cari } \\
\text { Oran. }\end{array}$ & $\begin{array}{l}\text { Nakit dönüş süresi ile firma kârlılığı arasında } \\
\text { negatif yönlü istatistiki olarak anlamlı } \\
\text { olmayan bir ilişki tespit edilmiştir. Alacak } \\
\text { tahsil süresi, cari oran ve kaldıraç oranının } \\
\text { firma kârlıı̆ı üzerinde istatistiksel olarak } \\
\text { anlamlı ve negatif bir etkisinin olduğu tespit } \\
\text { edilmiştir. Stok devir hızı ile kârlıık arasında } \\
\text { pozitif yönlü istatistiksel olarak anlamlı } \\
\text { olmayan bir ilişki tespit edilmiştir. }\end{array}$ \\
\hline 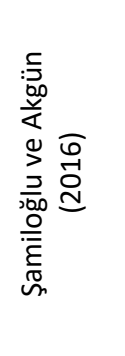 & $\begin{array}{l}\text { BiST İmalat Sektörü, } \\
120 \text { Firma, } 1.200 \\
\text { Gözlem, 2003-2012 }\end{array}$ & $\begin{array}{l}\text { Panel Veri } \\
\text { Analizi ve } \\
\text { Çoklu } \\
\text { Doğrusal } \\
\text { Regresyon }\end{array}$ & 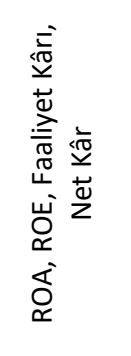 & $\begin{array}{l}\text { Alacak Devir Hızı, } \\
\text { Stok Devir Hızı, } \\
\text { Borç Ödeme } \\
\text { Süresi, Nakde } \\
\text { Dönüşüm Süresi, } \\
\text { Firma Büyüklüğü } \\
\text { ve Kaldıraç Oranı. }\end{array}$ & $\begin{array}{l}\text { Alacak tahsil süresi ile ROA, ROE, faaliyet kârı } \\
\text { ve net kâr arasında istatistiksel olarak anlamlı } \\
\text { ve negatif yönlü bir ilişki tespit edilmiştir. } \\
\text { Ayrıca faaliyet kârı ile alacak tahsil süresi ve } \\
\text { borç ödeme süresi arasında istatistiksel } \\
\text { olarak anlamlı ve negatif; stok tutma süresi } \\
\text { ve nakde dönüşüm süresi arasında pozitif ve } \\
\text { istatistiksel olarak anlamlı bir ilişki tespit } \\
\text { edilmiştir. }\end{array}$ \\
\hline 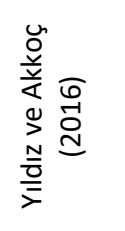 & $\begin{array}{l}\text { BisT Sanayi Sektörü, } \\
2.312 \text { Gözlem, 2000- } \\
2013\end{array}$ & $\begin{array}{l}\text { Uyarlanabilir } \\
\text { Sinirsel } \\
\text { Bulanık } \\
\text { Çıkarım } \\
\text { Sistemi } \\
\text { (ANFIS) }\end{array}$ & 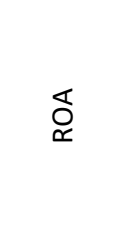 & $\begin{array}{l}\text { Cari Oran, Nakde } \\
\text { Dönüşüm Süresi. }\end{array}$ & $\begin{array}{l}\text { Elde edilen bulgular, çalışma sermayesi ve } \\
\text { kârlıı ilişkisinin doğrusal olmadığını } \\
\text { göstermektedir. }\end{array}$ \\
\hline
\end{tabular}

\section{Veri Seti ve Model}

Araştırmanın veri seti, 2003-2013 dönemi Borsa İstanbul (BiST)'daki dört sektörü (metal ana sanayi, gıda ve içecek, kimya-kauçuk ve plastik ürünler, tekstil ürünleri) kapsamaktadır. Sektörlerde yer alan firmalara ilişkin veriler üçer aylık dönemler halinde BiST'in resmi internet sitesinden, Kamuyu Aydınlatma Platformu'ndan (KAP) ve firmaların web sayfalarında yayınlanan mali tablolardan karşılaştırma ile sınanarak elde edilmiştir. Ayrıca araştırmanın makroekonomik değişkenleri olan reel gayrisafi yurtiçi hâsıla (GSYH'deki sabit fiyatlarla büyüme oranı modele dâhil edilmiştir) ve tüketici fiyatları endeksi (TÜFE), Türkiye Cumhuriyet Merkez Bankası Elektronik Veri Dağıtım Sistemi (EVDS) ve Türkiye İstatistik Kurumu (TÜiK) resmi internet sitesinden üçer aylık dönemler halinde elde edilmiştir. Çalışmada kullanılan değişkenlere ilişkin bilgiler tablo 3'te gösterilmiştir. Analizler için Gauss 9 ve Stata 14 programları kullanılmıştır. 
Tablo 3. Çalışmada Kullanılan Değişkenler

\begin{tabular}{|c|c|l|c|}
\hline Kod & \multicolumn{1}{|c|}{ Değişken } & \multicolumn{1}{c|}{ Açıklama } & Dönemi \\
\hline ROA & Aktif Kârlılığı & Net Kâr/Aktif Toplamı & $2003-2013$ \\
\hline NDS & Nakde Dönüşüm Süresi & (Alacak Tahsil Süresi + Stok Tutma Süresi)- Ticari Borç Ödeme Süresi & $2003-2013$ \\
\hline KLD & Kaldıraç Oranı & Toplam Yabancı Kaynak/Aktif Toplamı & $2003-2013$ \\
\hline ADH & Aktif Devir Hızı & Net Satışlar/Aktif Toplamı & $2003-2013$ \\
\hline GSYH & Gayrisafi Yurtiçi Hâsıla & $\begin{array}{l}\text { Türkiye Cumhuriyeti Merkez Bankası Elektronik Veri Dağıtım Sistemi } \\
\text { (EVDS)'den elde edilmiştir. }\end{array}$ & $2003-2013$ \\
\hline TÜFE & Tüketici Fiyatları Endeksi & $\begin{array}{l}\text { Türkiye Cumhuriyeti Merkez Bankası Elektronik Veri Dağıtım Sistemi } \\
\text { (EVDS)'den elde edilmiştir. }\end{array}$ & $2003-2013$ \\
\hline
\end{tabular}

Bu çalışmada tahmin edilen ekonometrik model (1) nolu eşitlikte gösterilmektedir.

$$
\mathrm{ROA}_{i \mathrm{t}}=\beta_{0}+\beta_{1} \mathrm{NDS}_{\mathrm{it}}+\beta_{2} \mathrm{KLD}_{\mathrm{it}}+\beta_{3} \mathrm{ADH}_{\mathrm{it}}+\beta_{4} \mathrm{GSYH}_{i \mathrm{t}}+\beta_{5} \mathrm{TÜFE}_{i \mathrm{t}}+\varepsilon_{\mathrm{it}}
$$

Kurgulanan modelde kullanılan bağımlı değişken ve bağımsız değişkenlere ait tanımlayıcı istatistikler (ortalama, medyan, standart sapma, minimum ve maksimum değerler) Tablo 4'te sunulmuştur.

Tablo 4. Değişkenlere İlişkin Tanımlayıcı İstatistikler

\begin{tabular}{lrrrrrr}
\hline Tanımlayıc İstatistikler & ROA & NDS & KLD & ADH & GSYH & TÜFE \\
\hline Ortalama & 2,70 & 98 & 0,49 & 0,56 & 0,05 & 153,89 \\
Medyan & 2,30 & 103 & 0,48 & 0,52 & 0,05 & 154,13 \\
Std. Sapma & 3,45 & 41 & 0,09 & 0,32 & 0,05 & 38,24 \\
Minimum & $-11,77$ & 2 & 0,30 & 0,13 & $-0,14$ & 96,38 \\
Maksimum & 13,36 & 189 & 0,81 & 2,04 & 0,11 & 222,84 \\
Gözlem Sayısı & 172 & 172 & 172 & 172 & 172 & 172 \\
& & & & & & \\
Korelasyon Matrisi & & & & & & \\
ROA & 1 & & & & & \\
NDS & $-0,25$ & 1 & & & & \\
KLD & $-0,13$ & $-0,27$ & 1 & & & \\
ADH & 0,38 & $-0,33$ & 0,12 & 1 & & \\
GSYH & 0,14 & $-0,19$ & 0,22 & $-0,01$ & 1 & \\
TÜFE & 0,22 & 0,07 & 0,20 & $-0,07$ & 0,22 & \\
\hline
\end{tabular}

Tablo 4'de görüleceği üzere ROA ile ADH arasında pozitif yönlü güçlü bir korelasyon vardır. Negatif yönlü en güçlü korelasyon ise nakde dönüşüm süresi ile aktif devir hızı arasındadır ancak analiz yapmak üzere tanımlayıcı istatistiklerin ötesinde güvenilir bir sonuç elde etmek için birim kök, eşbütünleşme ve uzun dönem katsayı tahminleri gibi daha güvenilir istatistiki yöntemlere ihtiyaç vardır.

\section{Ekonometrik Metodoloji}

Çalışmanın bu kısmında kullanılacak ekonometrik modellere ait metodoloji kısaca özetlenecektir. Panel veri analizinde kullanılacak birim kök ve eşbütünleşme testlerini belirlemek için öncelikle yapılması gereken yatay kesit bağımlılığının test edilmesidir. Bu kapsamda paneli oluşturan yatay kesitler arasında bir bağımlılık olup olmadığını belirlemek için Breusch ve Pagan (1980) LM (Lagrange Multiplier) testi, Pesaran 
(2004) tarafindan geliştirilen CD (Cross Section Dependent) ve $C_{\llcorner M}$ testleri ile Pesaran vd. (2008) tarafindan geliştirilen sapması düzeltilmiş $\mathrm{LM}_{\mathrm{adj}}$ (Bias-Adjusted Cross Sectionally Dependence Lagrange Multiplier) testi de dahil olmak üzere dört test uygulanmıştr. Çalışmamızda, seriler için birim kök analizi, yatay kesit bağımlıı̆ı altında, ikinci kuşak panel birim kök testlerinden Pesaran (2007) tarafindan geliştirilen CADF (CrossSectionally Augmented Dickey Fuller) testi ile yapılmıştır. Eşbütünleşme katsayılarının homojenliği başka bir ifade ile modeldeki bağımsız değişkenlerin katsayılarının yatay kesitten yatay kesite değişip değişmediği Pesaran ve Yamagata (2008) tarafindan geliştirilen Homojenite Testi ile incelenmiştir. Çalışmamızda seriler arasındaki eşbütünleşme ilişkisinin varlığı Westerlund (2008) tarafindan geliştirilen panel eş bütünleşme testi ile analiz edilmiştir. Panelin geneli ile uzun ve kısa döneme ait katsayıların tahmini ise Pesaran (2006) tarafindan geliştirilen ve yatay kesit bağımlııı̆ını göz önünde bulunduran Ortak iliş̧kili Etkiler (Common Correlated Effect (CCE)) ve Ortak ilişkili Etkiler Ortalama Grup (Common Correlated Effects Mean Group (CCEMG)) tahmincileriyle tahmin edilmiştir.

\subsection{Yatay Kesit Bağımlılık Testleri}

Breusch ve Pagan (1980) tarafindan geliştirilen ve eşitlik (2)'de görülen Lagrange Multiplier (LM) test istatistiği yatay kesit bağımlılık testlerinden ilkidir.

$$
L M=T \sum_{i=1}^{N-1} \sum_{j=i+1}^{N} \hat{\rho}_{i j}^{2}
$$

Burada, $\hat{\rho}_{\mathrm{ij}}$ eşitlik 2'in EKK yöntemiyle tahmininden elde edilen kalıntıların ikili korelasyonunun tahminidir. Birimler arasında yatay kesit bağımlılığının olmadığını ifade eden $\mathrm{H}_{0}$ hipotezi, yatay kesit bağımlıı̆ıının olduğunu ifade eden alternatif hipotez $\mathrm{H}_{1}$ karşısında test edilmektedir. $T \rightarrow \infty$ iken $\mathrm{N}$ sabit ise $\frac{N(N-1)}{2}$ serbestlik derecesinde ki-kare asimptotik dağılıma sahip olduğu ve bu testin zaman boyutu T'nin yatay kesit boyutu N'den büyük olduğu durumlarda kullanılacağı varsayılmaktadır (Peseran, 2004: 4; Güloğlu ve ìvrendi, 2010: 384).

Pesaran (2004), N büyük olduğunda bu testin kullanışsız olduğunu ifade etmektedir. İlk olarak $T \rightarrow \infty$ ve sonrasında $N \rightarrow \infty$ olan büyük paneller için Pesaran (2004) Breusch ve Pagan (LM) testinin eşitlik (3)'te ifade edilen geliştirilmiş halinin kullanımını önermektedir:

$$
C D_{L M}=\sqrt{\frac{1}{N(N-1)}} \sum_{i=1}^{N-1} \sum_{j=i+1}^{N}\left(T \hat{\rho}_{i j}^{2}-1\right)
$$

Bu teste göre $T \rightarrow \infty$ ve $N \rightarrow \infty$ olduğu durumda yatay kesit bağımlılığının olmadığı varsayılır. $\mathrm{CD}_{\text {Im }}$ testi, N büyük T küçük olduğunda önemli düzeyde bozulmalar göstermekte ve $N$ büyüdükçe sapmalar daha da artmaktadır. Pesaran (2004), N>T olduğu durumlarda yatay kesit bağımlılığı için CD testini geliştirmiştir. (4) nolu eşitlikte ifade edilen bu test $N^{\prime}$ nin T'den büyük olması ( $N>T$ ) durumunda kullanılmaktadır (Koçbulut ve Altnntaş, 2016:152-153).

$$
C D=\sqrt{\frac{2 T}{N(N-1)}} \sum_{i=1}^{N-1} \sum_{j=i+1}^{N} \hat{\rho}_{i j}
$$

Pesaran vd. (2008)'ne göre, CD testi ikili korelasyonların kitle ortalaması sıfirdan farklı olduğunda güç kaybetmektedir. Bu nedenle, Pesaran vd. (2008), ilk olarak $T \rightarrow \infty$ ve sonrasında $N \rightarrow \infty$ olan büyük paneller için bir LM testi geliştirmişlerdir. Bu test, (5) numaralı eşitlikte formüle edilmiş olan ve sapması düzeltilmiş $\mathrm{LM}_{\text {adj }}$ testidir. 
$L M_{a d j}=\sqrt{\frac{2}{N(N-1)}} \sum_{i=1}^{N-1} \sum_{j=i+1}^{N} T \hat{\rho}_{i j} \frac{(T-k) \hat{\rho}_{i j}^{2} \mu_{T i j}}{\sqrt{u_{T i j}^{2}}}$

Burada k açıklayıcı değişken sayısını gösterirken, $\mu_{T i j}$,

$(T-k) \hat{\rho}_{i j}^{2}$ 'nin ortalamasını, $u_{T i j}^{2}$ ise $(T-k) \hat{\rho}_{i j}^{2}$ 'nin varyansını göstermektedir (Pesaran vd. 2008: 108).

Tablo 5 çalışma kapsamında yapılan yatay kesit bağımlıı̆ı̆ı testlerinin sonuçlarını göstermektedir.

Tablo 5. Yatay Kesit Bağımlılığı Test Sonuçları

\begin{tabular}{|c|c|c|c|c|}
\hline \multirow[b]{2}{*}{ Değişkenler } & \multicolumn{4}{|c|}{ Yatay Kesit Bağımlılığı Testleri } \\
\hline & $\begin{array}{l}\text { LM (Breusch ve } \\
\text { Pagan, 1980) }\end{array}$ & CD (Pesaran 2004) & CD $D_{L M}$ (Pesaran 2004) & LMadj (Pesaran vd. 2008) \\
\hline ROA & $26.63[0.00]$ & $-4.48[0.00]$ & $6.07[0.00]$ & $21.48[0.00]$ \\
\hline NDS & $30.10[0.00]$ & $-3.58[0.00]$ & $12.43[0.00]$ & $25.15[0.00]$ \\
\hline KLD & $100.90[0.00]$ & $-9.83[0.00]$ & $17.13[0.00]$ & $99.95[0.00]$ \\
\hline $\mathrm{ADH}$ & $208.10[0.00]$ & $-14.38[0.00]$ & $13.86[0.00]$ & $213.10[0.00]$ \\
\hline $\begin{array}{l}\text { Eşbütünleşme } \\
\text { Denklemi }\end{array}$ & $34.68[0.00]$ & $5.72[0.00]$ & $8.28[0.00]$ & $49.67[0.00]$ \\
\hline
\end{tabular}

Not: CD test istatistiklerinde tablodaki köşeli parantez içindeki değerler olasılık değerlerini ifade etmektedir. Olasılık değerlerinin asimptotik olarak normal dağıldığı varsayılmaktadır.

Tablo 5'te görüldüğü gibi, $L M, C D, C D_{L M}$ ve $L M_{a d j}$ testlerinde değişkenlere ve eşbütünleşme denklemine ait olasılık değerleri 0,05 'ten küçük olduğu için $\mathrm{H}_{0}$ hipotezi $\% 1$ anlamlılık düzeyinde reddedilerek serilerde yatay kesit bağımlılı̆ının olduğu tespit edilmiştir. Yani değişkenler ve model için yapılan yatay kesit bağımlılık testleri yatay kesit bağımlılığının hem değişkenlerde hem de modelde var olduğunu göstermektedir. Değişkenlerde yatay kesit bağımlılığı tespit edildiğinden çalışmanın bundan sonraki aşamalarında yatay kesit bağımlılığını dikkate alan ikinci nesil panel birim kök testleri ve panel eşbütünleşme yöntemlerinin uygulanması daha doğru olacaktır.

\subsection{Panel Birim Kök Testi}

Seriler arasında uzun dönemli bir ilişkinin varlığını incelemek için öncelikle serilerin durağanlığı ve aynı dereceden eşbütünleşik olup olmadığı araştırılmalıdır. Panel veride yatay kesit bağımlıı̆ı̆ın olması durumunda ikinci nesil birim kök testlerinin kullanılması daha doğru olacaktır. Zira yatay kesit bağımlılı̆ının olması durumunda uygulanan birinci nesil panel birim kök testleri durağanlığı doğru şekilde ölçemeyecek bu durumun sonucu olarak sapmalı sonuçlar verebilmektedir. Her bir yatay kesitin hata terimlerinin bağımsız olduğunu ve yatay kesitlerin açıklayıcı değişkenlerden eşit derecede etkilendiğini varsayan birinci nesil birim kök testleri, kesitlerin birbiri ile bağlantısını dikkate alan ikinci nesil birim kök testlerine göre daha az gerçekçi bulunmaktadır. Birimlere ait seriler arasında korelasyon olduğunu varsayan başlıca ikinci nesil birim kök testlerine SURADF (Breuer, Mcknown ve Wallace, 2002), CADF (Pesaran, 2007), PANKPSS (Carrion-Silvestre vd., 2005) ve Hadri ve Kurozimi (2012) örnek olarak verilebilir (Gazel, 2016: 45-46).

Bu çalışmada, birim kökün varlığını tespit etmek üzere Pesaran (2007) tarafindan geliştirilen Yatay Kesit Genelleştirilmiş Dickey Fuller (CADF) testi kullanılmıştır. Bu testin en büyük özelliği yatay kesit bağımlılığını dikkate alması ve $\mathrm{N}>\mathrm{T}$ ya da $\mathrm{T}>\mathrm{N}$ olduğu durumlarda kullanılabilmesidir. Bu birim kök testinde hem CADF istatistiği ile her bir yatay kesite ait bireysel sonuçlar hem de kesit veri ortalamaları ile genişletilen 
CIPS (Cross sectionally IPS) istatistiği ile panelin geneline ilişkin sonuçlar elde edilmektedir (Pesaran, 2007: 266-267).

CADF testi aşağıdaki denklemi tahmin etmektedir (Pesaran, 2007: 268).

$$
\Delta y_{i t}=a_{i}+\beta_{i} y_{i, t-1}+\gamma_{i} f_{t}+\varepsilon_{i t}
$$

$$
\text { Burada, } a_{i}=\left(1-\phi_{i}\right) \mu_{i}, \beta_{i}=-\left(1-\phi_{i}\right) \text { ve } \Delta y_{i t}=y_{i t}-y_{i, t-1}
$$

$\phi_{i}=1$ olmak üzere CADF testinin boş hipotezi "serinin durağan olmadığını", alternatif hipotez ise "serinin durağanlığıı”" ifade eder. CADF testinde her bir yatay kesite ait birim kök test istatistiklerinin ortalaması alınarak panelin geneli için CIPS (Cross-Sectionally Augmented IPS) istatistiği kullanılabilir. CIPS istatistiği şu şekilde formüle edilir (Pesaran, 2007: 276).

$$
\operatorname{CIPS}(N, T)=t-b a r=N^{-1} \sum_{i=1}^{N} t_{i}(N, T)
$$

Paneli oluşturan her bir sektör için birim kök istatistikleri (CADF) ve panelin genelini değerlendirmek

\begin{tabular}{|c|c|c|c|c|c|c|c|c|c|c|c|c|c|c|c|c|}
\hline \multirow{2}{*}{ Sektör } & \multicolumn{2}{|c|}{ ROA } & \multicolumn{2}{|c|}{$\triangle \mathrm{ROA}$} & \multicolumn{2}{|c|}{ NDS } & \multicolumn{2}{|c|}{$\triangle \mathrm{NDS}$} & \multicolumn{2}{|c|}{ KLD } & \multicolumn{2}{|c|}{$\Delta \mathrm{KLD}$} & \multicolumn{2}{|c|}{$\mathrm{ADH}$} & \multicolumn{2}{|c|}{$\triangle \mathrm{ADH}$} \\
\hline & $C A D F$ & $\rho$ & $C A D F$ & $\rho$ & CADF & $\rho$ & $C A D F$ & $\rho$ & $C A D F$ & $\rho$ & $C A D F$ & $\rho$ & CADF & $\rho$ & $C A D F$ & $\rho$ \\
\hline Metal & $-1,62$ & 1 & $-5,03^{* * *}$ & 1 & $-3,01$ & 2 & $-3,46^{*}$ & 4 & $-0,60$ & 1 & $-5,05^{* * *}$ & 1 & $-1,77$ & 1 & $-2,45$ & 1 \\
\hline Gıda & $-2,76$ & 1 & $-4,76^{* * *}$ & 2 & $-2,24$ & 1 & $-3,07$ & 3 & $-0,38$ & 3 & $-5,41^{* * *}$ & 1 & $-1,46$ & 1 & $-4,00^{* * *}$ & 2 \\
\hline Kimya & $-2,37$ & 2 & $-5,98^{* * *}$ & 1 & $-2,00$ & 1 & $-5,10^{* * *}$ & 2 & $-1,32$ & 1 & $-2,89$ & 5 & $-1,56$ & 1 & $-4,83^{* * *}$ & 1 \\
\hline Tekstil & $-4,05^{* * *}$ & 1 & $-4,63^{* * *}$ & 4 & $-3,20$ & 1 & $-5,81^{* * *}$ & 1 & $-0,44$ & 1 & $-3,82^{* *}$ & 1 & 0,80 & 1 & $-2,88$ & 1 \\
\hline CIPS & \multicolumn{2}{|c|}{$-2,70$} & \multicolumn{2}{|c|}{$-5,01^{* * *}$} & \multicolumn{2}{|c|}{$-2,61$} & \multicolumn{2}{|c|}{$-4,34^{* * *}$} & \multicolumn{2}{|c|}{$-0,69$} & \multicolumn{2}{|c|}{$-4,29^{* * *}$} & \multicolumn{2}{|c|}{$-0,998$} & \multicolumn{2}{|c|}{$-3,54^{* * *}$} \\
\hline
\end{tabular}
için kullanılan CIPS istatistikleri tablo 6'da yer almaktadır.

Tablo 6. CADF Birim Kök Testi Sonuçları

Sektörler ve panelin geneli için kritik değerler Pesaran'ın (2007) çalışmasından elde edilmiştir. Sektörler için kritik değerler \%1, \%5 ve \%10 için sırasıyla -4.49, -3.78, -3.44 iken panelin geneli için kritik değerler \%1, \%5 ve \%10 için sırasıyla; -3.06, -2.84, 2.73'tür. ${ }^{* * *},{ }^{* *}$, , sırasıyla $\% 1, \% 5$ ve $\% 10$ seviyelerinde anlamlıı̆̆ı göstermektedir. Fark operatörü $(\Delta)$ değişkenin farkını göstermektedir. Tabloda p ile gösterilen sütunlar gecikme uzunluklarını göstermektedir. Tüm değişkenler için sabitli ve trendli model seçilmiştir.

Tablo 3 incelendiğinde panelin genelini değerlendirmemizi sağlayacak olan CIPS istatistiği, serilerin seviyede durağan olmayıp birinci farkları alındığında durağan olduklarını göstermektedir. Bu sonuçlara göre serilerde birim kökün olduğunu varsayan $\mathrm{H}_{0}$ hipotezi reddedilmemekte ve serilerin aynı düzeyde bütünleşik [I(1)] olduğuna karar verilmektedir.

\subsection{Eşbütünleşme Katsayılarının Homojenliğinin Test Edilmesi}

Çalışmanın bundan sonraki aşamalarında uygulanacak analiz yöntemlerinin seçilmesinde ve daha gerçekçi yorumlar yapılabilmesi için panel veri analizinde eğim katsayılarının homojenliğinin test edilmesi gerekmektedir. Panel veri analizinde homojenlikle ilgili ilk çalışmalar Swamy (1970) tarafindan gerçekleştirilmiştir. (8) nolu eşitlik Swamy testini $(\hat{S})$ göstermektedir. Eğim heterojenliğini test etmek için Pesaran ve Yamagata (2008) delta testlerini $(\tilde{\Delta})$ kullanmaktadırlar. Eğim homojenliğini ifade eden sıfir hipotezi, ( $\mathrm{HO}: \beta i=\beta$ tüm i'ler için), eğim heterojenliğini ifade eden alternatif hipoteze (H1: $\beta i \neq \beta$ bazı i'ler için), karşı test edilmektedir (Pesaran ve Yamagata, 2008: 54-55). 


$$
\hat{S}=\sum_{i=1}^{N}\left(\hat{\beta}_{i}-\hat{\beta}_{W F E}\right)^{\prime} \frac{X_{i}^{\prime} M_{\tau} X_{i}}{\hat{\sigma}_{i}^{2}}\left(\hat{\beta}_{i}-\hat{\beta}_{W F E}\right)
$$

ve

$$
\hat{\sigma}_{i}^{2}=\frac{\left(y_{i}-X_{i} \hat{\beta}_{i}\right)^{\prime} M_{\tau}\left(y_{i}-X_{i} \hat{\beta}_{i}\right.}{(T-k-1)}
$$

Burada $M_{\tau}$ birim matris olup, $\widehat{\beta}_{\text {WFE }}$ ağırlıklandırılmış sabit etki havuzlanmış tahmincidir. Söz konusu tahminci şu şekilde hesaplanmaktadır:

$$
\hat{\beta}_{W F E}=\left(\sum_{i=1}^{N} \frac{X_{i}^{\prime} M_{\tau} X_{i}}{\hat{\sigma}_{i}^{2}}\right)^{-1} \sum_{i=1}^{N} \frac{X_{i}^{\prime} M_{\tau} y_{i}}{\hat{\sigma}_{i}^{2}}
$$

Hata terimlerinin normal dağılması koşuluyla ve $(N, T) \rightarrow \infty$ ve $\sqrt{N} / T \rightarrow 0$ olmak kaydıyla, test istatistiği şu şekilde tanımlanmaktadır:

$$
\begin{array}{ll}
\text { Büyük örneklemler için: } & \hat{\Delta}=\sqrt{N}\left(\frac{N^{-1} \hat{S}-k}{\sqrt{2 k}}\right) \\
\text { Küçük örneklemler için: } & \tilde{\Delta}_{a d j}=\sqrt{N}\left(\frac{N^{-1} \tilde{S}-k}{\sqrt{2 k}}\right)
\end{array}
$$

Burada N; yatay kesit sayısını, S; Swamy test istatistiğini, k; açıklayıcı değişken sayısını göstermektedir (Pesaran ve Yamagata, 2008: 52-57).

Delta Testinin boş hipotez "Eğim Katsayılarının Homojen" olduğunu ifade etmektedir. Çalışmamızda eşbütünleşme katsayılarının homojen olup olmadığına ilişkin sonuçlar Tablo 7'de rapor edilmiştir.

Tablo 7. Eş Bütünleşme Katsayılarının Homojenliğinin Test Edilmesi

\begin{tabular}{|c|c|c|}
\hline & Test İstatistiği & Olasılık Değeri \\
\hline$\Delta$ & $32.7503^{*}$ & 0.000 \\
\hline$\Delta$ adj & $36.2068^{*}$ & 0.000 \\
\hline
\end{tabular}

Not: Test istatistikleri sonuçlarına göre *, **, *** sırasıyla $\% 1, \% 5$ ve $\% 10$ düzeylerindeki istatistiksel anlamlılı̆ı ifade etmektedir.

Tablo 7'de hesaplanan homojenlik testlerinin olasılık değerleri 0,05 'ten küçük olduğu için $\mathrm{H}_{0}$ hipotezi güçlü bir şekilde reddedilmiş ve eşbütünleşme denklemlerindeki eğim katsayılarının heterojen olduğuna karar verilmiştir.

\subsection{Westerlund (2007) ECM Panel Eşbütünleşme Testi}

Serilerin I(1) oldukları tespit edildiği için aralarında eşbütünleşme ilişkisinin varlığı test edilmelidir. Bu amaçla hem yatay kesit bağımlıı̆ı̆ını hem de heterojeniteyi dikkate alan Westerlund (2007) panel eşbütünleşme testinden yararlanılmıştır. Bu test hata düzeltme terimine (Error Correction Term, ECT) dayalı bir testtir. Westerlund $(2007)^{1}$, hata düzeltme modeli temelli 4 adet panel eşbütünleşme testi önermiştir. 
Testlerin temelinde her bir birimin kendi hata düzeltmesine sahip olup olmadığına karar verilmesi yoluyla eşbütünleşme varlığını sınamak vardır. Bu testlerden Pa ve Pt tüm panele ait bilgiler ile hesaplanan test istatistikleri iken $\mathrm{Ga}$ ve $\mathrm{Gt}$ ise grup ortalamalarına dayalı test istatistikleridir. Her iki grup testte de $\mathrm{H}_{0}$ hipotezinin reddedilmesi, panelin tümü için eşbütünleşme ilişkisinin reddi anlamına gelmektedir (Tatoğlu, 2013: 239-240).

Tablo 8'de $G_{t}, G_{a}$, $P_{t}$ ve $P_{a}$, test istatistik değerleri, olasılık değerleri ve yatay kesit veri bağımlılığına karşı dirençli olasııık (robust $p$-values) değerleri yer almaktadır.

Tablo 8. Westerlund (2007)-ECM Eşbütünleşme Test Sonuçları

\begin{tabular}{|c|c|c|c|}
\hline Testler & İstatistik & Olasılık Değeri & Bootstrap Olasılık Değeri \\
\hline $\mathrm{G}_{\mathrm{t}}$ & -3.48 & $0.03^{* *}$ & $0.02^{* *}$ \\
\hline $\mathrm{G}_{\mathrm{a}}$ & -22.86 & $0.02^{* *}$ & $0.00^{*}$ \\
\hline $\mathrm{Pt}_{\mathrm{t}}$ & -7.17 & $0.01^{* *}$ & $0.04^{* *}$ \\
\hline $\mathrm{Pa}$ & -23.7 & $0.00^{*}$ & $0.00^{*}$ \\
\hline
\end{tabular}

ifade etmektedir.

Tablo 8'de elde edilen sonuçlar, paneli oluşturan yatay kesit birimleri arasında eşbütünleşik ilişki yoktur $\mathrm{H}_{0}$ hipotezinin reddedildiğini göstermektedir. Başka bir ifade ile paneli oluşturan 4 sektörden en az biri için söz konusu değişkenler arasında bir eşbütünleşme ilişkisi olduğu saptanmıştır.

\subsection{Uzun Dönem Eşbütünleşme Katsayılarının Tahmin Edilmesi}

Panel Dinamik En Küçük Kareler Yöntemi gibi metotlar sadece uzun dönem parametrelerini tahmin etmek için geliştirilmiştir. Uzun dönem parametrelerinin yanında kısa dönem parametrelerinin tahminleri de önemli bilgiler vermektedir. Havuzlanmış Ortalama Grup Tahmincisi (PMGE), Ortalama Grup Tahmincisi (MGE) ve Dinamik Sabit Etkiler Tahmincisi (DFE), hata düzeltme modeli oluşturarak hem kısa hem de uzun dönem parametrelerini birlikte tahmin etmektedirler. PMGE, uzun dönem parametrelerini sabit tutarken, kısa dönem parametreleri ve hata varyansının birimlere göre değerlenmesine izin vermektedir. Dinamik Sabit Etkiler Tahmincisi ise, hata düzeltme modelini sabit etkiler varsayımıyla tahmin etmekte, tüm parametreleri sabit tuttuğu için birimlere göre hesaplamalar yapmamaktadır. Hata Düzeltme Modeli (Tatoğlu, 2013: 243244);

$$
\Delta Y_{i t}=\phi_{i} Y_{i t-1}+\beta_{i}^{\prime} X_{i t}+\sum_{j=1}^{p-1} \lambda_{i j} \Delta Y_{i t-j}+\sum_{j=0}^{q-1} \delta_{i j} \Delta X_{i t-j}+\varepsilon_{i t}
$$

Burada $\phi_{i}$ hata düzeltme parametresini ifade etmekle birlikte,

$$
\phi_{i}=-\left(1-\sum_{j=1}^{p} \lambda_{i j}\right), \beta_{i}=\sum_{j=0}^{q} \delta_{i j}, \lambda_{i j}^{*}=-\sum_{m=j+1}^{p} \lambda_{i m}, \delta_{i j}^{*}=-\sum_{m=j+1}^{q} \delta_{i m}
$$

Eşitlik (13) ve (14)'te $\phi_{i}$, anlamlı ve negatif ise $Y_{i t}$ ile $X_{i t}$ arasında uzun dönemli ilişkinin olduğunu göstermektedir.

Tahminciler arasında seçim yapmak için kullanılabilen Hausman testi, Havuzlanmış Ortalama Grup Tahmincisi ile Ortalama Grup Tahmincisi arasında seçim yapabilmek için de kullanılabilmektedir. Havuzlanmış Ortalama Grup Tahmincisi (PMGE) uzun dönem parametresi tüm birimler için sabit, bir başka ifade ile homojen ve Ortalama Grup Tahmincisi (MGE) ise birimlere göre değişmektedir, bir başka ifade ile uzun 
dönem parametreleri heterojendir (Tatoğlu, 2013: 255-256). Bu bilgi kullanılarak PMGE ve MGE tahmincileri arasında tercih yapmak için Hausman testi sonucu Tablo 9'da verilmiştir.

Tablo 9. Hausman Testi Sonuçları

\begin{tabular}{|c|c|c|}
\hline Test Özeti & Test İstatistiği & Olasılık Değeri \\
\hline Uzun Dönem Parametresinin Homojenliği & 0.68 & 0.983 \\
\hline
\end{tabular}

Hausman testi sonucuna göre, $\mathrm{H}_{0}$ hipotezi reddedilmemiş ve $\mathrm{H}_{0}$ hipotezi altında daha etkin olan Havuzlanmış Ortalama Grup Tahmincisinin (PMGE) kullanılmasının uygun olduğu yönünde bulgulara ulaşılmıştır. Uzun dönem parametreleri birimlere göre homojendir, başka bir ifade ile birimden birime değişmemektedir.

Çalışmada panel hata düzeltme modeli Havuzlanmış Ortalama Grup Tahmincisi ile tahmin edilmiştir. Sonuçlar Tablo 10'da rapor edilmiştir.

Tablo 10. Havuzlanmış Ortalama Grup Tahmincisi Sonuçları

\begin{tabular}{|c|c|c|c|}
\hline Açıklayıcı Değişkenler & Katsayı & Standart Hata & p Değeri \\
\hline & \multicolumn{3}{|c|}{ Uzun Dönem Katsayıları } \\
\hline NDS & $-.03209^{* *}$ & .01579 & 0.042 \\
\hline KLD & $0.042^{* *}$ & 5.7863 & 0.045 \\
\hline ADH & .74808 & 1.6818 & 0.656 \\
\hline TUFE & .00896 & .00945 & 0.343 \\
\hline \multirow[t]{2}{*}{ GSYH } & $15.049^{* *}$ & 5.9852 & 0.012 \\
\hline & \multicolumn{3}{|c|}{ Hata Düzeltme Katsayısı } \\
\hline \multirow[t]{2}{*}{$\phi_{i}$} & $-.47095^{*}$ & .08186 & 0.000 \\
\hline & \multicolumn{3}{|c|}{ Kısa Dönem Katsayıları } \\
\hline NDS & .00857 & .01078 & 0.427 \\
\hline KLD & -5.9726 & 5.0874 & 0.240 \\
\hline ADH & $3.4283^{*}$ & .89977 & 0.000 \\
\hline TUFE & -.02065 & .02525 & 0.413 \\
\hline GSYH & -3.2073 & 3.4585 & 0.354 \\
\hline CONS. & $-.99647^{* *}$ & .46276 & 0.031 \\
\hline
\end{tabular}

Tablo 10'da panel hata düzeltme modelinin Havuzlanmış Ortalama Grup Tahmincisi (PMGE) ile tahmini görülmektedir. Sonuçlara göre, hata düzeltme parametresi $(-0.470)$ negatif ve istatistiksel olarak anlamlıdır, Aktif Kârlııı̆ı, Nakde Dönüşüm Süresi, Kaldıraç Oranı, Aktif Devir Hızı, Tüketici Fiyatları Endeksi ve Gayri Safi Yurtiçi Hâsıla değişkenleri arasında analize dâhil edilen sektörler bazında uzun dönemli bir ilişki mevcuttur. Bu parametre, serilerin durağan olmamasından kaynaklanan kısa dönem sapmalarının bir sonraki dönemde dengeye gelme hızını göstermektedir. Zira hata düzeltme katsayısı bir dönemde oluşan dengesizliklerin yaklaşık \%47'si bir sonraki dönemde düzelecek ve uzun dönem dengesine yaklaşması sağlanacaktır. Ayrıca nakde dönüşüm süresinin uzun dönem parametresi (-.03) istatistiksel olarak anlamlı ve işareti beklenildiği gibi negatiftir. Yani uzun dönemde nakde dönüşüm süresindeki düşüş (kısalma), kârlıık düzeyini panel genelinde artırmaktadır. Teorik olarak kârlılık düzeyini artırabilmek için nakde dönüşüm 
süresinin düşürülmesi gerekmektedir. Elde edilen bu bulgu beklentiyi destekler niteliktedir. Kaldıraç oranının uzun dönem parametresi (0.04) istatistiksel olarak anlamlı ve işareti pozitiftir. Bu durumu, borçlanma düzeyini artırarak kaldıraç etkisinden yararlanmak ve kârlılığı artırmak mümkündür şeklinde açıklamak mümkündür. Gayri Safi Yurtiçi Hasılanın uzun dönem parametresi (15.04) istatistiksel olarak anlamlı ve işareti pozitiftir. Gayrisafi yurtiçi hasılanın artı̧̧ gösterdiği dönemlerde bireylerin kullanılabilir gelirlerinde dolayısıyla da mal ve hizmetlere olan taleplerinde artş beklenir. Ekonomik canlılıkla beraber işletmelerin satş hacimlerinin artması ve kârlılık düzeylerinin yükselmesi beklenir. Çalışmadan elde edilen bulgu bu beklentiyi destekler niteliktedir. Aktif Devir Hızının ve Tüketici Fiyatları Endeksinin uzun dönem katsayılarının işareti pozitif ancak istatistiksel olarak anlamsızdır.

Tablo 10'da kısa dönem parametrelerine bakıldığında sadece Aktif Devir Hızı katsayısının \%1 seviyesinde anlamlı olduğu, Nakde Dönüşüm Süresi, Kaldıraç Oranı, Tüketici Fiyatları Endeksi ve Gayri Safi Yurtiçi Hâsıla değişkenleri için katsayıların istatistiksel olarak anlamlı olmadığı gözlenmektedir. Aktif devir hızının kısa dönem parametresi (3.42) istatistiksel olarak anlamlı ve işareti beklenildiği üzere pozitiftir. Varlık devir hızını artırarak kârlııık düzeyini artırmak beklenen bir sonuçtur.

Bu çalışmada uzun dönem eşbütünleşme katsayılarını tahmin etmek için Pesaran (2006) tarafindan geliştirilen ve yatay kesit bağımlılı̆ını dikkate alan Ortak ilişskili Etkiler Ortalama Grup (Common Correlated Effects Mean Group - CCEMG) yöntemi kullanılmış ve sonuçlar karşılaştııılmıştır. Pesaran (2006), yatay kesit bağımlılığı altında uzun dönem ilişkisini tespit edebilmek için Ortak iliş̧kili Etkiler (Common Correlated EffectsCCE) tahmincilerini geliştirmiştir. Bu uzun dönem katsayı tahmincileri Ortak İlişkili Etkiler Ortalama Grup (Common Correlated Effects Mean Group - CCEMG) tahmincisi ve Ortak iliş̧kili Etkiler Havuzlanmış (Common Correlated Effects Pooled - CCEP) tahmincisidir. Bireysel eşbütünleşme katsayılarının tahmin edilmesini sağlayan CCE tahmincisi $N, T \rightarrow \infty$ olduğunda tutarlıdır ve asimptotik dağılım gösterir (Pesaran, 2006: 969).

CCE yöntemi (15) nolu eşitlikteki panel veri regresyon modeline dayanmaktadır (Pesaran, 2006: 971):

$$
\begin{aligned}
& y_{i t}=a_{i}^{\prime} d_{t}+\beta_{i}^{\prime} x_{i t}+e_{i t} \quad i=1,2, \ldots, \mathrm{N} \quad t=1,2, \ldots, \mathrm{T} \\
& e_{i t}=\gamma_{i}^{\prime} f_{t}+\varepsilon_{i t}
\end{aligned}
$$

CCEMG tahmincisi, her bir yatay kesit için uzun dönem eşbütünleşme katsayılarını (16) nolu eşitlik ile hesaplar.

$$
\hat{\mathrm{b}}_{\mathrm{MG}}=\mathrm{N}^{-1} \sum_{\mathrm{i}=1}^{\mathrm{N}} \hat{\mathrm{b}}_{\mathrm{i}}
$$

Burada $\hat{b}_{i}$ her bir yatay kesitin bireysel eğim katsayısı için CCE tahminini verir. CCEMG tahmincisi her bir yatay kesite ait katsayıların aritmetik ortalamasını alarak uzun dönem eşbütünleşme katsayılarını hesaplar (Pesaran, 2006: 982-986).

Tablo 11'de CCEMG tahmin sonuçları yer almaktadır.

Tablo 11'deki sonuçlar incelendiğinde Nakde Dönüşüm Süresi, Kaldıraç Oranı ve Aktif Devir Hızı değişkenleri için uzun dönem eşbütünleşme katsayılarının istatistiksel olarak anlamlı olduğu, Tüketici Fiyatları Endeksi ve Gayri Safi Yurtiçi Hasıla değişkenlerine ilişkin katsayıların ise istatistiksel olarak anlamlı olmadığı gözlenmektedir. Havuzlanmış Ortalama Grup Tahmincisi (PMGE) ve Ortak Iilişkili Etkiler Ortalama Grup (CCEMG) tahmincisi sonuçları değerlendirildiğinde hem hata düzeltme katsayısı hem de değişkenlere ilişkin katsayılar uzun dönemde bir iliş̧inin varlığına işaret etmektedir. 
Tablo 11. CCEMG Tahmin Sonuçları

\begin{tabular}{|c|c|c|c|}
\hline Açıklayıcı Değişkenler & Katsayı & Standart Hata & t İstatistiği \\
\hline NDS & $-.047^{* *}$ & .020 & -2.37 \\
\hline KLD & $5.476^{* * *}$ & 3.293 & 1.662 \\
\hline ADH & $15.051^{*}$ & 2.841 & 5.297 \\
\hline TUFE & -.003 & .015 & -0.247 \\
\hline GSYH & .270 & 4.955 & 0.054 \\
\hline
\end{tabular}

Not: $\mathrm{t}$ istatistiğinin hesaplanmasında; Newey-West değişen varyans standart hatası kullanılmıştır. ${ }^{*}, * *$ ve ${ }^{* * *}$, sırasıyla $\% 1, \% 5$ ve $\% 10$ düzeylerinde anlamlılığı ifade etmektedir.

\section{Sonuç}

Bu çalışmada Borsa İstanbul'dan seçilen metal ana sanayi, gıda ve içecek, kimya-kauçuk ve plastik ürünler, tekstil ürünleri sektörleri bazında 2003-2013 dönemi arası üçer aylık veriler kullanılarak aktif karlılığı üzerinde nakde dönüşüm süresi, kaldıraç oranı, aktif devir hızı, gayrisafi yurtiçi hasıla ve tüketici fiyatları endeksi arasındaki uzun dönemli eşbütünleşme ilişkisinin varlığı; yatay kesit bağımlılı̆ı altında ikinci nesil panel birim kök, panel eşbütünleşme, uzun ve kısa dönemli katsayı tahmini gibi ekonometrik teknikler kullanılarak tespit edilmeye çalışıımıştır.

Analiz sonuçları Aktif Kârlııı̆ı ile Nakde Dönüşüm Süresi, Kaldıraç Oranı, Aktif Devir Hızı Tüketici Fiyatları Endeksi ve Gayri Safi Yurtiçi Hasıla arasındaki ilişkinin metal ana sanayi, gıda ve içecek, kimya-kauçuk ve plastik ürünler, tekstil ürünleri sektörleri için kısa ve uzun dönem için farklılaştğını göstermektedir. Havuzlanmış Ortalama Grup Tahmincisi (PMGE) sonuçlarına göre uzun dönemde ilgili sektörler için aktif kârııı̆ı ile söz konusu değişkenler arasında teorik olarak bir ilişkinin varlığını ifade eden bir katsayı (-0.470) elde edilmiştir. PMGE sonuçlarına göre uzun dönemde nakde dönüşüm süresinin, kaldıraç oranının ve gayri safi yurtiçi hasılanın katsayıları istatistiksel olarak anlamlıdır. Bu sonuçlara göre nakde dönüşüm süresinin uzamasının kârlılık üzerinde negatif etki yarattı̆ııı; yabancı kaynaklardan yararlanmanın ve gayri safi yurtiçi hasılanın kârlılığı pozitif yönde etkilediğini söylemek mümkündür. Diğer taraftan Havuzlanmış Ortalama Grup tahmincisiyle kısa dönemde sadece Aktif Devir Hızının katsayısının anlamlı olduğu diğer değişkenlerin ise istatistiksel olarak anlamlı olmadığı tespit edilmiştir. Kısa vadede aktif devir hızının yani firma varlıklarının etkinliğinin arttırılmasının kârlııı̆ı pozitif yönde etkilediğini söylemek mümkündür. Analizde uzun dönemli ilişkiye daha fazla odaklanmak için yatay kesit bağımlılı̆ını göz önünde bulunduran Ortak illişkili Etkiler Ortalama Grup (CCEMG) yöntemine yer verilmiştir. CCEMG analiz sonuçları Nakde Dönüşüm Süresi, Kaldıraç Oranı ve Aktif Devir Hızı katsayılarının uzun dönemli bir ilişkinin varlığı için anlamlı olduklarını göstermektedir.

Bu çalışmada mikro verilerle sektör bazında yapılan analiz sonuçlarının literatüre katkı sağlaması amaçlamaktadır. Bundan sonraki çalışmalarda, değişkenlerin çeşitlendirilmesinin ve daha uzun gözlemler aracılığıyla etkilerinin tespit edilmesinin faydalı olacağı düşünülmektedir.

\section{Son Notlar}

1. Westerlund (2007)'nin eşbütünleşme testi ile ilgili detaylı açıklamalar için J. Westerlund, 2007; 709-748 bakılabilir. 


\section{Kaynaklar}

Ademola, J. (2014). Working capital management and profitability of selected quoted food and beverages manufacturing firms in Nigeria. European Journal of Accounting Auditing and Finance Research, 2(3), 10-21.

Afza, T., \& Nazir, M. S. (2008). Working capital approaches and firm's returns in Pakistan. Pakistan Journal of Commerce and Social Sciences, Vol. 1, 25-36.

Akel, V., \& Gazel, S. (2014). Döviz kurları ile BIST Sanayi Endeksi arasındaki eşbütünleşme ilişkisi: Bir ARDL sınır testi yaklaşımı. Erciyes Üniversitesi Iktisadi ve Idari Bilimler Fakültesi Dergisi, 44, 23-41.

Aygün, M. (2012). Firma performansı üzerinde çalışma sermayesinin etkisi: Türk imalat sektörü üzerine bir uygulama. Ege Akademik Bakıs Dergisi, 12(2), 215-223.

Büyükşalvarcı, A., \& Abdioğlu, H. (2010). Kriz öncesi ve kriz dönemlerinde işletmelerde çalışma sermayesi gereksiniminin belirleyicileri: IMKB imalat sanayi şirketleri üzerine ampirik bir uygulama. Atatürk Üniversitesi iktisadi ve idari Bilimler Dergisi, 24(2), 47-71.

Caballero, S. B., Teruel, P. J. G., \& Solano, P. M. (2010). Working capital management in SMEs. Accounting and Finance, 50(2010), 511-527.

Ceylan, A., \& Korkmaz, T. (2008). İsletmelerde finansal yönetim (10. Basım). Bursa. Ekin Basım Yayın Dağıtım.

Coşkun, E., \& Kök, D. (2011). Çalışma sermayesi politikalarının kârııık üzerine etkisi: Dinamik panel uygulaması. Ege Akademik Bakış Dergisi, 11, 75-85.

Çakır, M, H., \& Küçükkaplan, ì. (2012). İşletme sermayesi unsurlarının firma değeri ve kârılığı üzerindeki etkisinin IMKB'de işlem gören üretim firmalarında 2000-2009 dönemi için analiz. Muhasebe ve Finansman Dergisi, 53, 6986.

Çakır, M, H. (2013). Nakit döngüsünün firma kârlılığına etkisini sektörel analizi. Journal of Yaşar University, 30(8), 49484965.

Deloof, M. (2003). Does working capital management affect profitability of Belgian firms? Journal of Business Finance and Accounting, 30(3/4), 573-587.

Dursun, A., \& Ayrıçay, Y. (2012). Çalışma sermayesi-kârlıık ilişkisinin iMKB örneğinde 1996-2005 dönemi analizi. Atatürk Üniversitesi iktisadi ve Idari Bilimler Dergisi, 26( 3-4), 199-215.

Eljelly, A. M. (2004). Liquidity - profitability tradeoff an empirical Investigation in an emerging market. International Journal of Commerce and Management, 14(2), 48-61.

Gazel, S. (2016). Finansal gelişme ve ekonomik büyüme ilişkisi: 1990-2014 yılları zordaki onlu ülkeler uygulaması. Business and Economics Research Journal, 7(3), 39-52.

Gill, A. (2011). Factors that influence working capital requirements in Canada. Economics and Finance Review, 1(3), 3040.

Gill, A., Biger, N., \& Mathur, N. (2010). The relationship between working capital management and profitability: Evidence from the United States. Business and Economics Journal, Volume 2010: BEJ-10, 1-9.

Güloğlu, B., \& İvrendi, M. (2010). Output fluctuations: Transitory or permanent? The case of Latin America. Applied Economics Letters, 17, 381-386.

Işık, E., \& Kiracı, M. (2012). 2008 küresel finansal krizin işletmelerin çalışma sermayeleri üzerindeki etkilerinin oranlar aracilı̆ıyla tespiti: iMKB'de bir araştirma. Muhasebe ve Finansman Dergisi, 54, 157-174.

Jose, M. L., Lancaster, C., \& Stevens, J. L. (1996). Corporate returns and cash conversion cycles. Journal of Economics and Finance, 20(1), 33-46.

Karaduman, H. A., Akbaş, H. E., Özsözgün, A., \& Durer, S. (2010). Effects of working capital management on profitability: The case for selected companies in the İstanbul Stock Exchange (2005-2008). International Journal of Economics and Finance Studies, 2(2), 47-54.

Kendirli, S., \& Konak, F. (2014). İşletme (çalışma) sermayesi yönetiminin firma performansı üzerindeki etkisi: BiST gıda, içecek endeksi uygulaması. Akademik Bakış Dergisi, 41(3).

Keskin, R., \& Gökalp, F. (2016). Çalışma sermaye yönetiminin firma kârlılı̆ı üzerine etkisi: Panel veri analizi. Doğuş Üniversitesi Dergisi, 17(1), 15-25. 
Koçbulut, Ö., \& Altıntaş, H. (2016). İkiz açıklar ve Feldstein-Horika Hipotezi: OECD ülkeleri üzerine yatay kesit bağımlılı̆̆ altında yapısal kırılmalı panel eşbütünleşme analizi. Erciyes Üniversitesi Iktisadi ve Idari Bilimler Fakültesi Dergisi, 48, 145-174.

Lazaridis, I., \& Tryfonidis, D. (2006). Relationship between working capital management and profitability of listed companies in the Athens Stock Exchange. Journal of Financial Management and Analysis, 19(1), 26 - 35.

Mathuva, D. M. (2010). The influence of working capital management components on corporate profitability: A survey on Kenyan listed firms. Research Journal of Business Management, 4(1), 1-11.

Nazir, M. S., \& Afza, T. (2009). Impact of aggressive working capital management policy on firms' profitability. The IUP Journal of Applied Finance, 15(8), 19-30.

Nazlıoğlu, Ş. (2010). Makro iktisat politikalarının tarım sektörü üzerindeki etkileri: Gelişmiş ve gelişmekte olan ülkeler için bir karşılaştırma. Erciyes Üniversitesi Sosyal Bilimler Enstitüsü, Yayınlanmamış Doktora Tezi, Kayseri.

Öz, Y., \& Güngör, B. (2007). Çalışma sermayesi yönetiminin firma karlılığı üzerine etkisi: İmalat sektörüne yönelik panel veri analizi. Atatürk Üniversitesi Sosyal Bilimler Enstitüsü Dergisi, 10(2), 319-332.

Öztürk, M. B., \& Demirgüneş, K. (2008). İşletme sermayesi gereksinimini etkileyen değişkenler üzerine iMKB'de bir uygulama. Finans Politik \& Ekonomik Yorumlar, 45(516), 47-56.

Padachi, K. (2006). Trends in working capital management and its impact on firms' performance: An analysis of Mauritian small manufacturing firms. International Review of Business Research Papers, 2(2), 45-58.

Pesaran, M. H. (2004). General diagnostic tests for cross section dependence in panels. University of Cambridge Working Paper, 0435,http://papers.ssrn.com/sol3/papers.cfm?abstract_id=572504, Erişim Tarihi: 10.04.2017.

Pesaran, M. H. (2006). Estimation and inference in large heterogeneous panels with a multifactor error structure. Econometrica, 74(4), 967-1012.

Pesaran, M. H. (2007). A simple panel unit root test in the presence of cross section dependence. Journal of Applied Econometrics, 22(2), 265-312.

Pesaran, M. H., Ullah, A., \& Yamagata, T. (2008). A bias-adjusted LM test of error cross-section independence. The Econometrics Journal, 11(1), 105-127.

Pesaran, M. H, Ullah, A., \& Yamagata, T. (2008). Testing slope homogeneity in large panels. Journal of Econometrics, 142(1), 50-93.

Raheman, A., \& Nasr, M. (2007). Working capital management and profitability - Case of Pakistani firms. International Review of Business Research Papers, 3(1), $279-300$.

Ramachandran, A., \& Janakiraman, M. (2009). The relationship between working capital management efficiency and EBIT. Managing Global Transitions, 7(1), 61-74.

Shin, H. H., \& Soenen, L. (1998). Effciency of working capital management and corporate profitability. Financial Practice and Education, 8(2), 37-45.

Şamiloğlu, F., \& Demirgüneş, K. (2008). The effect of working capital management on firm profitability: Evidence from Turkey. The International Journal of Applied Economics and Finance, 2(1), 44-50.

Şamiloğlu, F., \& Akgün, A. İ. (2016). The relationship between working capital and profitability: Evidence from Turkey, Business and Economics Research Journal, 7(2), 1-14.

Şen, M., \& Oruç, E. (2009). Relationship between efficiency level of working capital management return on total assets in ISE. Tntemational Journal of Business and Management, 4(10), 109-114.

Tatoğlu, F.Y. (2013). Ileri panel veri analizi-Stata uygulamalı (2.Baskı). İstanbul: Beta Basım Yayın Dağıtım A.Ş.

Teruel P. G., \& Solano, P. M. (2007). Effects of working capital management on SME profitability. International Journal of Managerial Finance, 3(2), 164-177.

Ukaegbu, B. (2014). The significance of working capital management in determining firm profitability: Evidence from developing economies in Africa. Research in International Business and Finance, 31(2014), 1-16.

Uyar, A. (2009). The Relationship of cash conversion cycle with firm size and profitability: An empirical investigation in Turkey. International
Finance and Economics, 24, 186-193.

Vural, G., Sökmen, A. G., \& Çetenak, E. H. (2012). Affects of working capital management on firm's performance: evidence from Turkey. International Journal of Economics and Financial Issues, 2(4), 488-495. 
Yıldız, B., \& Akkoç, S. (2016). Çalışma sermayesi ve kârlılık ilişkisinin keşifsel bir araçla (ANFIS) incelemesi. Eskişehir Osmangazi Üniversitesi iiBF Dergisi, 11(1), 285-308.

Yücel, T., \& Kurt, G.. (2002). Nakit dönüş süresi, nakit yönetimi ve kârlılık: iMKB şirketleri üzerinde ampirik bir çalışma. iMKB Dergisi, 6(22), 1-15.

Westerlund, J. (2007). Testing for error correction in panel data. Oxford Bulletion of Economics and Statistics, 69, 709-748.

Wu, C., \& Ho, S. J. K.. (1997). Financial ratio adjustment: Industry-wide effects or strategic management. Review of Quantitative Finance and Accounting, 9(1), 71-88. 